\title{
Carbon Dioxide Concentrations and Light Levels on Growth and Mineral Nutrition of Juvenile Cacao Genotypes
}

\author{
Virupax C. Baligar1 ${ }^{*}$, Marshall K. Elson', Alex-Alan F. Almeida ${ }^{2}$, \\ Quintino R. de Araujo ${ }^{2}$, Dario Ahnert ${ }^{2}$, Zhenli He ${ }^{3}$ \\ ${ }^{1}$ USDA-ARS-Beltsville Agricultural Research Center, Beltsville, USA \\ ${ }^{2}$ Department of Biological Science, State University of Santa Cruz, Ilhéus, Brazil \\ ${ }^{3}$ Indian River Research and Education Center, IFAS, University of Florida, Fort Pierce, USA \\ Email: ${ }^{\star V}$.C.Baligar@usda.gov
}

How to cite this paper: Baligar, V.C., Elson, M.K., Almeida, A.-A.F., de Araujo, Q.R., Ahnert, D. and He, Z.L. (2021) Carbon Dioxide Concentrations and Light Levels on Growth and Mineral Nutrition of Juvenile Cacao Genotypes. American Journal of Plant Sciences, 12, 818-839.

https://doi.org/10.4236/ajps.2021.125056

Received: April 10, 2021

Accepted: May 25, 2021

Published: May 28, 2021

Copyright $\odot 2021$ by author(s) and Scientific Research Publishing Inc. This work is licensed under the Creative Commons Attribution International License (CC BY 4.0).

http://creativecommons.org/licenses/by/4.0/

\begin{abstract}
In many countries cacao (Theobroma cacao L.) is invariably grown as an understory crop in agroforestry types of cropping systems and subjected to low levels photosynthetic photon flux density (PPFD) due to presence of large number of upper story shade trees with poorly managed canopy structure. In recent years carbon dioxide concentration in the atmosphere is steadily increasing and it is unclear what impact this will have on performance of cacao grown under shade of upper story shade trees. A climatically controlled greenhouse experiment was undertaken to evaluate the effects of ambient and elevated carbon dioxide ( 400 and $700 \mu \mathrm{mol} \cdot \mathrm{mol}^{-1}$ ) and three levels of PPFD $\left(100,200\right.$, and $\left.400 \mu \mathrm{mol} \cdot \mathrm{m}^{-2} \cdot \mathrm{s}^{-1}\right)$ on growth, and macro- and micronutrient use efficiency of three genetically contrasting cacao genotypes (CCN 51, VB 1117 and NO 81). Intraspecific variations were observed in cacao genotypes for growth parameters at ambient to elevated carbon dioxide and low to adequate levels of PPFD. With the exceptions of total root length and leaf area, irrespective of carbon dioxide and PPFD levels, all three genotypes showed significant differences in all the growth parameters. For all the cacao genotypes, increasing PPFD from 100 to $400 \mu \mathrm{mol} \cdot \mathrm{m}^{-2} \cdot \mathrm{s}^{-1}$ and carbon dioxide from 400 to $700 \mu \mathrm{mol} \cdot \mathrm{mol}^{-1}$ increased overall growth parameters such as leaf, shoot and root biomass accumulation, stem height, leaf area, relative growth rate and net assimilation rate. Irrespective of carbon dioxide and PPFD, invariably genotypes differed significantly in macro-micronutrient uptake parameters such as concentration, uptake, influx, transport and use efficiency. With few exceptions, raising PPFD from 100 to $400 \mu \mathrm{mol} \cdot \mathrm{m}^{-2} \cdot \mathrm{s}^{-1}$ and carbon dioxide from 400 to $700 \mu \mathrm{mol} \cdot \mathrm{mol}^{-1}$ increased nutrient use efficiency for all
\end{abstract}


the cacao genotypes. Elevated carbon dioxide and adequate PPFD are beneficial in improving cacao growth and mineral nutrient uptake and use efficiency.

\section{Keywords}

Relative Growth Rate, Net Assimilation Rate, Mineral Nutrient Influx and Transport, Mineral Nutrient, Uptake Efficiency

\section{Introduction}

Cacao (Theobroma cacao L.) is native to the understory of Amazonian forests of South America, and botanically its characteristics are similar to shade adapted species rather than sun plants [1] [2] [3] [4]. Shade is better for growth and development of young cacao; however, heavy shade is detrimental to growth and production of mature and older trees [5] [6] [7] [8]. There is no universal agreement on the degree of shade required to maximize cacao production [9] [10] [11] [12]. Almeida and Valle [11] stated that cocoa is a $C_{3}$ species which prefers full sun, but is tolerant to moderate shading, due to its phenotypic plasticity acclimatization to moderate shade conditions. Depending on the climatic and ecological conditions of the area, cacao is cultivated under different cropping systems from full sun (open canopy) to managed and unmanaged multi-strata agroforestry, where it is planted together with various types of shade trees such as fruit, timber, firewood, and leguminous trees, or within thinned native forests [13]-[19]. Shade trees in multi-strata agroforestry systems of cacao planting are known to buffer cacao from climate changes, improve soil fertility and regulate pathogens and pests, thereby improving cacao sustainability and cacao production. Shade trees also provide other sources of income for farmers [6] [14] [20] [21] [22] [23].

In agroforestry systems, cacao is subjected to different light intensities, depending on the density of single or multi strata shade trees, types of shade trees and level of vegetative cover and extent of shade tree pruning adopted if any [10] [21] [24]. The intensity and quality of light falling on a cacao tree are known to affect its growth and yield but there is no universal agreement on the intensity and quality of light required to maximize its production [6] [10] [15] [25] [26]. The nature and density of leaf cover of upper story trees affect light reaching field grown understory plants and under such situations light could be low in PPFD with low R/FR ratio [27] [28].

In early stages of growth, cacao grows well under shade and needs shade to reduce nutrient and water stresses [2] [10] [25]. Lower yields in cacao grown under shade are mostly related to climatic conditions such as reduced light intensity, precipitation, temperature [20] [22] [23] [29] and therefore under such management systems it is advantageous to adopt cacao genotypes that can maintain desired productivity even under reduced light intensity. 
Optimum cacao growth is achieved at $20 \%$ to $30 \%$ of full sunlight [1] [30] usually with adequate soil nutrient availability [31]. Under shaded plantations in Bahia Brazil, light intensity at noon above the cacao canopy ranged between 30 and $100 \%$ of the full sunlight and $4 \%-10 \%$ at the ground level [32]. It has been reported that the PPFD for maximum net photosynthesis (PN) in cacao occurs at about 350 to $550 \mu \mathrm{mol} \cdot \mathrm{m}^{-2} \cdot \mathrm{s}^{-1}$, which is about $20 \%$ to $25 \%$ of the intensity of full sunlight [12] [33] [34] [35] [36]. In the cacao growing regions, Hutcheon [33] has shown that the maximum light saturation point in cacao was $250-300$ $\mu \mathrm{mol} \cdot \mathrm{m}^{-2} \cdot \mathrm{s}^{-1}$, which is about $15 \%$ of the full midday sunlight. Variations in morphological characteristics among cacao genotypes have been reported [4] [37] [38] [39] and these characteristics have been influenced by light level [1] [12] [40] [41] [42]. Plant traits could have great implications on the ability of plants to intercept and utilize solar radiation. Baligar et al. [40] reported that in juvenile cacao genotypes increasing PPFD from 65 to $190 \mu \mathrm{mol} \cdot \mathrm{m}^{-2} \cdot \mathrm{s}^{-1}$ increased shoot and root growth and net assimilation rate (NAR), however, PPFD of 1050 $\mu \mathrm{mol} \cdot \mathrm{m}^{-2} \cdot \mathrm{s}^{-1}$ was detrimental to early cacao growth. In seven genetically different cacao genotypes, Baligar et al. [43] reported that increasing PPFD from 100 to $400 \mu \mathrm{mol} \cdot \mathrm{m}^{-2} \cdot \mathrm{s}^{-1}$ increased shoot and root growth, relative growth rate (RGR) and net assimilation rates (NAR). Irrespective of levels of PPFD significant intraspecific differences between genotypes were observed for shoot and root growth.

In many plant species demands for mineral nutrients are greatly influenced by the light levels that reach the canopy [44] [45] [46] [47]. Baligar et al. [40] reported that in cacao genotype comum increasing PPFD from 65 to 1050 $\mu \mathrm{mol} \cdot \mathrm{m}^{-2} \cdot \mathrm{s}^{-1}$ increased the nutrient use efficiency (NUE) for $\mathrm{N}, \mathrm{Na}, \mathrm{S}$ and $\mathrm{Zn}$ and decreased NUE for other nutrients. Recently the existence of intraspecific differences in cacao genotypes has been reported for macro-micro nutrient uptake and use efficiency [43], and these nutrient traits increased with increasing PPFD from 100 to $400 \mu \mathrm{mol} \cdot \mathrm{m}^{-2} \cdot \mathrm{s}^{-1}$. However, information is limited on the influence of various light levels on NUE of cacao genotypes.

The present carbon dioxide concentration $\left[\mathrm{CO}_{2}\right]$ in the atmosphere is around $400 \mu \mathrm{mol} \cdot \mathrm{mol}^{-1}$ and based on future emission scenarios, it could reach as high as 550 to $1370 \mu \mathrm{mol} \cdot \mathrm{mol}^{-1}$ by the end of the $21^{\text {st }}$ century [48] [49]. In older plantations, cacao is invariably subjected to low light levels coupled with increasing global atmospheric $\left[\mathrm{CO}_{2}\right]$ and reduced availability of soil nutrients and water that could have negative effects on growth and production potentials of cacao. Both light levels and photoperiod are of importance in determining plant responses to elevated $\left[\mathrm{CO}_{2}\right][50]$. Elevated $\left[\mathrm{CO}_{2}\right]$ has contributed to increased biomass of tropical plants [51] [52] [53] [54] and increased growth and development of cacao [12] [40]. Compared to row crops and temperate tree crops, information is very much lacking on the effects of low levels of PPFD and increasing levels of $\left[\mathrm{CO}_{2}\right]$ and their interactions on morphological development and NUE of cacao. Baligar et al. [40] reported that increasing external atmospheric 
$\left[\mathrm{CO}_{2}\right]$ from 380 to $700 \mu \mathrm{mol} \cdot \mathrm{mol}^{-1}$ increased root, shoot and leaf dry biomass, stem height, leaf area, shoot/root ratio, relative growth rate (RGR), and net assimilation rate (NAR) in Forestaro type cacao. Further in that study, increasing $\left[\mathrm{CO}_{2}\right]$ increased NUE for $\mathrm{N}, \mathrm{Na}, \mathrm{Mg}, \mathrm{Cu}, \mathrm{Mn}$, and $\mathrm{Zn}$ and decreased NUE for other mineral nutrients. Baligar et al. [43] reported that in seven cacao genotypes, irrespective of PPFD levels, increasing $\left[\mathrm{CO}_{2}\right]$ from 400 to $700 \mu \mathrm{mol} \cdot \mathrm{mol}^{-1}$ significantly increased shoot and root weight, root length, stem height, leaf area, specific leaf area, RGR, NAR, and macro-micro nutrient uptake and NUE.

Identification of plant traits for growth, physiological and NUE that are influenced by low PPFD at elevated $\left[\mathrm{CO}_{2}\right]$ can help to identify cacao genotypes that could perform well under a range of $\left[\mathrm{CO}_{2}\right]$ and light intensities. The objectives of this study were to evaluate the effects of ambient and elevated $\mathrm{CO}_{2}$ concentrations at varying low to adequate light levels on growth, and macro- and micronutrient use efficiency in three genetically contrasting cacao genotypes.

\section{Materials and Methods}

\subsection{Cacao Genotypes}

Three cacao genotypes, CCN 51, VB 1117, and NO 81, were selected for this study. Pods of various cacao genotypes needed for this research were received from the MARS Center for Cocoa Science, Alimirante, Itajuipe, Bahia, Brazil. CCN 51 is a clone from Ecuador obtained from crosses of ICS $95 \times$ IMC 6. ICS 95 is a Trinitario clone with parental contributions from lower Amazon Forestero and Criollo [55] [56], whereas IMC 67 is an upper Amazon Forestero collected from Peru [55]. VB 1117 is an Amelonado clone selected from Almirante, Bahia, Brazil for tolerance to witches' broom disease (Moniliophthora pernicosa). NO 81 is derived from crosses of IMC $47 \times$ PA 107 [57]. Additional information on cacao clones used is given by Turnbull and Hadley [57] and Ahnert and Eskes [58]. Seeds used for this study were produced by self-pollination. Therefore, the full sib family plants generated by such seeds have, on average, similar traits to the parents, in this case, the clonal cuttings.

\subsection{Growth Medium}

The growth medium was prepared by mixing Perlite: Sand: Promix (2:2:1 volume basis) in a cement mixer. Supplemental nutrients were added at the time of mixing to provide $600 \mathrm{mg} / \mathrm{kg} \mathrm{N}, 600 \mathrm{mg} / \mathrm{kg} \mathrm{P}, 240 \mathrm{mg} / \mathrm{kg} \mathrm{K}, 1012 \mathrm{mg} / \mathrm{kg} \mathrm{Ca}, 309$ $\mathrm{mg} / \mathrm{kg} \mathrm{Mg}, 119 \mathrm{mg} / \mathrm{kg} \mathrm{Fe}, 0.7 \mathrm{mg} / \mathrm{kg} \mathrm{B}, 17.5 \mathrm{mg} / \mathrm{kg} \mathrm{Mn}, 7 \mathrm{mg} / \mathrm{kg} \mathrm{Cu}, 7 \mathrm{mg} / \mathrm{kg} \mathrm{Zn}$ and $0.35 \mathrm{mg} / \mathrm{kg}$ Mo. Pots were watered on a daily basis to maintain water content at the field water holding capacity.

\subsection{Growth Conditions}

Seeds were separated from cacao pods and seed coats were removed by hand. Seeds were soaked in $10 \%$ chlorine bleach (Sodium hypochlorite) for $2 \mathrm{~min}$, rinsed twice in deionized-water, then soaked in $90 \%$ ethanol for 2 min and 
rinsed twice in DI-water. Seeds were germinated on sterile moist filter paper for $48 \mathrm{~h}$ at $25^{\circ} \mathrm{C} \pm 2^{\circ} \mathrm{C}$. Seeds with $5 \mathrm{~mm}$ radicals were planted in $3.8 \mathrm{~L}$ black plastic pots with adequate bottom drainage containing $2.2 \mathrm{~kg}$ of the growth medium. One seedling was planted in each pot. During the growth phase soil moisture was kept at field capacity $(-33 \mathrm{kPa})$ by adding water every other day. On the $21^{\text {st }}$ day of growth, an initial plant harvest was made for initial growth.

\section{4. $\mathrm{CO}_{2}$ and PPFD Treatments}

For this study two air-conditioned greenhouses $\left(13.5 \mathrm{~m}^{2}\right.$ each $)$ with day/night temperatures of $30^{\circ} \mathrm{C} / 28^{\circ} \mathrm{C}$ were used to conduct two independent experiments with ambient and elevated $\mathrm{CO}_{2}$. One greenhouse contained near ambient $\left[\mathrm{CO}_{2}\right]$ $\left(400 \pm 50 \mu \mathrm{mol} \cdot \mathrm{mol}^{-1}\right)$ and the other had elevated $\left[\mathrm{CO}_{2}\right]\left(700 \pm 50 \mu \mathrm{mol} \cdot \mathrm{mol}^{-1}\right)$. The $\mathrm{CO}_{2}$ concentration of $700 \mu \mathrm{mol} \cdot \mathrm{mol}^{-1}$ was controlled by a WMA2 infra-red gas analyzer (PP Systems, Amesbury, MA, USA) which injected $\mathrm{CO}_{2}$ when the concentrations fell below the desired $\left[\mathrm{CO}_{2}\right]$. Ambient night-time $\mathrm{CO}_{2}$ concentration values were higher than $400 \mu \mathrm{mol} \cdot \mathrm{mol}^{-1}$ at this site due in part to low wind speed and stable atmospheric conditions. Within each greenhouse, electrical fans continuously circulated the air at an air speed of $0.5 \mathrm{~m} \cdot \mathrm{s}^{-1}$ over the plants. Day-time air temperatures were maintained for $12 \mathrm{~h}$ per day beginning at $6 \mathrm{AM}$. The greenhouses transmitted approximately $60 \%$ of the incident PPFD daily. A data logger (21×, Campbell Scientific, Logan, UT, USA) recorded the PPFD, temperature and $\left[\mathrm{CO}_{2}\right]$ in both greenhouses at $30 \mathrm{~s}$ intervals. In each greenhouse two mini chambers were utilized to achieve different PPFD. Mini chambers were constructed with $2 \mathrm{~cm}$ (3/4 inch) diameter PVC pipe with overall dimensions of $60 \mathrm{~W} \mathrm{~cm} \times 120 \mathrm{~L} \mathrm{~cm} \times 81 \mathrm{H} \mathrm{cm}$. To achieve different levels of light, tops and sides of mini chambers were covered with plastic shade cloth. A single-ply of Easy Gardener ${ }^{\circledR}$ sun screen fabric provided the minimum PPFD of $100 \pm 20$ $\mu \mathrm{mol} \cdot \mathrm{m}^{-2} \cdot \mathrm{s}^{-1}$, a single-ply of black window screen provided medium PPFD of $200 \pm 30 \mu \mathrm{mol} \cdot \mathrm{m}^{-2} \cdot \mathrm{s}^{-1}$ and the absence of shade cloth was the third treatment which provided PPFD of $400 \pm 40 \mu \mathrm{mol} \cdot \mathrm{m}^{-2} \cdot \mathrm{s}^{-1}$. On every $7^{\text {th }}$ sunny day, at midday, PPFD were determined with a Li-Cor LI-190S Quantum sensor (Li-Cor Inc., Lincoln, NE, USA) in the mini chambers and in the greenhouses; these values do not represent PPFD of daily mean and do not include overcast days. Mini chambers were covered with mesh shade cloth so they had full air exchange with the greenhouse atmosphere. Plants in each mini chamber were rotated once a week to keep the light exposures constant.

\subsection{Determination of Growth Parameters}

The experiment was terminated after 90 days of growth in the mini-chambers. Stem height was recorded. Leaves were separated from stems and the leaf area was determined by a Li-Cor model 3100 leaf area meter (Li-Cor Inc., Lincoln, NE, USA). Roots and shoots were separated and washed with deionized water. Shoots were blotted dry, oven dried at $70^{\circ} \mathrm{C}$ for 5 days and weighed. The roots 
were removed from the soil, washed, blotted dry and weighed. Root lengths were determined with a Comair Root Length Scanner (Hawker de Haviland, Melbourne, Victoria, Australia). Roots were oven dried at $70^{\circ} \mathrm{C}$ for 5 days and the dry root weights were recorded.

The following growth parameters were determined.

$$
\begin{aligned}
& \text { Specific Leaf Area }\left(\mathrm{SLA}, \mathrm{cm}^{2} \cdot \mathrm{g}^{-1}\right)=\frac{\text { Total leaf area }\left(\mathrm{cm}^{2} / \text { plant }\right)}{\text { Total leaf dry weight }(\mathrm{g} / \text { plant })} \\
& \text { Leaf Mass/Unit Leaf Area }\left(\mathrm{LMA}, \mathrm{g} \cdot \mathrm{cm}^{-2}\right)=\frac{1}{\mathrm{SLA}} \\
& \text { Leaf Area Ratio(LAR, } \left.\mathrm{cm}^{2} \cdot \mathrm{g}^{-1}\right)=\frac{\text { Total leaf area }\left(\mathrm{cm}^{2} / \text { plant }\right)}{\text { Shoot }+ \text { Root dry wt. }(\mathrm{g} / \text { plant })} \\
& \text { Relative Growth Rate }\left(\mathrm{RGR}, \mathrm{g} \cdot \mathrm{g}^{-1} \cdot \mathrm{d}^{-1}\right)=\frac{\ln \left(W t_{2} / W t_{1}\right)}{T_{2}-T_{1}}
\end{aligned}
$$

where $W t$ is total weight (shoot + root), $T$ is time in days, subscripts 1 and 2 refer to initial and final plant harvests.

$$
\text { Net Assimilation Rate }\left(\mathrm{NAR}, \mathrm{g} \cdot \mathrm{cm}^{-2} \cdot \mathrm{d}^{-1}\right)=\mathrm{RGR} / \mathrm{LAR}
$$

\subsection{Determination of Nutrient Uptake Parameters}

Dried shoot samples were ground to pass through a $1 \mathrm{~mm}$ mesh sieve. Chemical analysis of the shoot samples was performed at the Indian River Research and Education Center, University of Florida, Fort Pierce, FL, USA. Plant tissues (0.4 g) were digested in $5 \mathrm{~mL}$ of concentrated $14 \mathrm{~N} \mathrm{HNO}_{3}$ [59]. The concentrations of macro- ( $\mathrm{P}, \mathrm{K}, \mathrm{Ca}$, and $\mathrm{Mg}$ ) and micro-elements ( $\mathrm{B}, \mathrm{Cu}, \mathrm{Fe}, \mathrm{Mn}$, and $\mathrm{Zn}$ ) in the digested solution were analyzed using inductively coupled plasma optical emission spectrometry (ICPOES Ultima, J. Y. Horiba Group, Edison, NJ, USA) following USEPA method 200.7 [60]. Total $\mathrm{N}$ in the plant tissue was analyzed by combustion method using CN Analyzer (Vario MAX CN Macro Analyzer, Elementar Analysensysteme GmbH, Hanau, Germany) [61].

Nutrient uptake (U), influx (IN), transport (TR) and use efficiency (NUE) were calculated as follows:

$$
\begin{aligned}
& \operatorname{Uptake}(\mathrm{U})= \text { Conc. of any given element }(\mathrm{mg} / \mathrm{g} \text { or } \mu \mathrm{g} / \mathrm{g}) \\
& \times \text { Shoot dry weight }(\mathrm{g} / \text { plant }) \\
& \operatorname{Influx}(\mathrm{IN})=\frac{\left(\left(U_{2}-U_{1}\right) /\left(T_{2}-T_{1}\right)\right)\left(\ln W r_{2}-\ln W r_{1}\right)}{W r_{2}-W r_{1}}
\end{aligned}
$$

where $U$ refers to elemental content in shoot (mmoles/plant), $T$ is time in seconds, $W r$. is total root length (cm/plant), and subscripts 1 and 2 refer to initial and final plant harvest times.

$$
\operatorname{Transport}(\mathrm{TR})=\frac{\left(\left(U_{2}-U_{1}\right) /\left(T_{2}-T_{1}\right)\right)\left(\ln W s_{2}-W s_{1}\right)}{W s_{2}-W s_{1}}
$$


where $U$ refers to elemental content in shoot (mmoles/plant), $T$ is time in seconds, $W s$ is shoot dry weight (g/plant).

Nutrient Use Efficiency $(\mathrm{NUE})=\frac{\mathrm{mg} \text { of } W s}{\mathrm{mg} \text { of any given element in shoot }}$

\subsection{Statistical Analysis}

A Split-Split plot design was used, where $\mathrm{CO}_{2}$ treatments were the main plots, PPFD were the sub plots and genotypes were the sub-sub plots. Experimental units were replicated four times. Results were subjected to analysis of variance using general linear model (GLM) procedures of SAS (Ver. 9.1, SAS Institute, Cary, NC).

\section{Results and Discussion}

\section{1. $\left[\mathrm{CO}_{2}\right]$ and PPFD Effects on Growth Parameters}

Genotypic variations in growth parameters (shoot and root weight, root length, stem height, leaf area, specific leaf area, and RGR) were influenced by genotypes, $\left[\mathrm{CO}_{2}\right]$ and PPFD (Table 1 and Table 2). Growth and development of cacao are profoundly influenced by genetic, physiological and morphological determinants and their interaction with environmental variables such as PPFD and $\left[\mathrm{CO}_{2}\right]$ [11] [12] [40]. With the exceptions of total root length and leaf area, irrespective of $\left[\mathrm{CO}_{2}\right]$ and PPFD, all genotypes showed significant differences in the growth parameters. Overall NO 81 genotype had higher values for all the growth parameters as compared to the other two genotypes. Cacao genotypes vary in morphological characteristics [37] [38] [39] and cacao morphological characteristics are influenced by the light level [1] [12] [40] [41] [42]. Elevated $\left[\mathrm{CO}_{2}\right.$ ] increases plant growth such as shoot and root biomass, leaf and root area, RGR and nutrient uptake; however, the magnitude of such responses is dependent on the availability of water and mineral nutrients, and environmental variables such as light and temperature [1] [36] [40] [41] [52] [53] [54] [62] [63] [64].

Irrespective of genotypes and PPFD, increasing $\left[\mathrm{CO}_{2}\right]$ from 400 to 700 $\mu \mathrm{mol} \cdot \mathrm{mol}^{-1}$ in-creased overall growth parameters, however, significant influences were observed for shoot and root biomass accumulations, plant height, leaf area and RGR. Effects of elevated $\left[\mathrm{CO}_{2}\right]$ on morphological and growth parameters of tropical plants has received considerably less attention than temperate plants. Increasing $\left[\mathrm{CO}_{2}\right]$ in tree species increased dry matter accumulation and mean mass per unit leaf [65]. Nine tropical plant species subjected to elevated (2x ambient) $\left[\mathrm{CO}_{2}\right]$ increased dry matter and $\mathrm{P}_{\mathrm{N}}$ [66]. In seven $\mathrm{C}_{3}$ crops and three weed species, Bunce [67] reported that increasing $\left[\mathrm{CO}_{2}\right]$ from 360 to 700 $\mu \mathrm{mol} \cdot \mathrm{mol}^{-1}$ increased dry mass, RGR and NAR.

Baligar et al. [40] grew cacao genotype comum for 57 days at $\mathrm{CO}_{2}$ concentrations of 380 (ambient) and $700 \mu \mathrm{mol} \cdot \mathrm{mol}^{-1}$ (elevated) and plants grown at 700 $\mu \mathrm{mol} \cdot \mathrm{mol}^{-1}$ had increased root, shoot and leaf dry masses, leaf area, stem height, root/shoot ratio and RGR as compared to plants grown at ambient $\left[\mathrm{CO}_{2}\right]$. In a 
recent study, Baligar et al. [43] reported that shoot and root growth of seven genetically different cacao genotypes increased with increasing $\left[\mathrm{CO}_{2}\right]$ from 400 to $700 \mu \mathrm{mol} \cdot \mathrm{mol}^{-1}$. Results of the current study supported these earlier findings. Generally, $\mathrm{C}_{3}$ plants respond positively to elevated $\mathrm{CO}_{2}$ [68]. In the current study, increasing $\left[\mathrm{CO}_{2}\right]$ from 400 to $700 \mu \mathrm{mol} \cdot \mathrm{mol}^{-1}$ reduced SLA. Bunce [69] reported increased growth in annual plants due to reduced LAR at elevated $\left[\mathrm{CO}_{2}\right]$. Lahive et al. [64] reported that juvenile Amelonado cacao grown under elevated $\left[\mathrm{CO}_{2}\right]$ increased stem elongation, leaf fresh and dry biomass, and leaf

Table 1. The effect of $\left[\mathrm{CO}_{2}\right]$ and photosynthetic photon flux density (PPFD) on shoot and root growth of three cacao genotypes.

\begin{tabular}{|c|c|c|c|c|c|c|c|c|c|c|}
\hline \multirow{2}{*}{$\begin{array}{c}{\left[\mathrm{CO}_{2}\right]} \\
\left(\mu \mathrm{mol} \cdot \mathrm{mol}^{-1}\right)\end{array}$} & \multirow{2}{*}{$\begin{array}{c}\text { PPFD } \\
\left(\mu \mathrm{mol} \cdot \mathrm{m}^{-2} \cdot \mathrm{s}^{-1}\right)\end{array}$} & \multicolumn{4}{|c|}{ Dry Weights (g/plant) } & \multirow{2}{*}{$\begin{array}{l}\text { Stem Height } \\
\text { (cm/plant) }\end{array}$} & \multirow{2}{*}{$\begin{array}{c}\text { Root } \\
\text { Length } \\
\text { (cm/plant) }\end{array}$} & \multirow{2}{*}{$\begin{array}{l}\text { Root/ } \\
\text { Shoot } \\
\text { Ratio }\end{array}$} & \multirow{2}{*}{$\begin{array}{c}\text { RGR } \\
\left(\mathrm{g} \cdot \mathrm{g}^{-1} \cdot \mathrm{d}^{-1}\right) \\
\left(\times 10^{-2}\right)\end{array}$} & \multirow{2}{*}{$\begin{array}{c}\text { NAR } \\
\left(\mathrm{g} \cdot \mathrm{cm}^{-2} \cdot \mathrm{d}^{-1}\right) \\
\left(\times 10^{-4}\right)\end{array}$} \\
\hline & & Leaf & Shoot & Root & Total & & & & & \\
\hline \multicolumn{11}{|c|}{ CCN 51} \\
\hline \multirow[t]{3}{*}{400} & 100 & 5.90 & 7.69 & 1.60 & 9.30 & 32.0 & 4211 & 0.21 & 3.49 & 1.54 \\
\hline & 200 & 6.53 & 8.66 & 1.74 & 10.41 & 27.5 & 3262 & 0.20 & 3.64 & 1.76 \\
\hline & 400 & 16.83 & 21.27 & 4.31 & 25.58 & 43.0 & 5917 & 0.21 & 4.64 & 2.49 \\
\hline \multirow[t]{4}{*}{700} & 100 & 7.39 & 9.55 & 2.15 & 11.70 & 41.8 & 4355 & 0.23 & 3.76 & 1.64 \\
\hline & 200 & 11.54 & 15.27 & 2.85 & 18.12 & 45.5 & 5645 & 0.18 & 4.23 & 2.24 \\
\hline & 400 & 23.02 & 32.80 & 7.41 & 40.21 & 60.3 & 5600 & 0.23 & 5.14 & 3.87 \\
\hline & & & VB & & & & & & & \\
\hline \multirow[t]{3}{*}{400} & 100 & 6.87 & 9.02 & 1.28 & 10.30 & 46.8 & 3942 & 0.14 & 3.86 & 2.02 \\
\hline & 200 & 10.96 & 15.33 & 2.30 & 17.63 & 55.0 & 4745 & 0.15 & 4.48 & 3.28 \\
\hline & 400 & 13.23 & 19.56 & 2.78 & 22.34 & 56.0 & 4851 & 0.14 & 4.71 & 3.91 \\
\hline \multirow[t]{3}{*}{700} & 100 & 11.37 & 15.95 & 1.81 & 17.76 & 76.5 & 5664 & 0.11 & 4.49 & 2.60 \\
\hline & 200 & 16.77 & 24.24 & 2.96 & 27.19 & 84.5 & 6075 & 0.12 & 4.96 & 3.34 \\
\hline & 400 & 22.75 & 35.27 & 5.16 & 40.43 & 99.0 & 4869 & 0.14 & 5.39 & 4.21 \\
\hline \multicolumn{11}{|c|}{ NO 81} \\
\hline \multirow[t]{3}{*}{400} & 100 & 7.49 & 9.57 & 1.59 & 11.16 & 48.5 & 5131 & 0.17 & 3.82 & 1.82 \\
\hline & 200 & 11.23 & 14.50 & 2.07 & 16.57 & 48.5 & 5681 & 0.13 & 4.20 & 2.29 \\
\hline & 400 & 22.07 & 29.08 & 4.61 & 33.70 & 63.3 & 5996 & 0.16 & 5.04 & 3.67 \\
\hline \multirow[t]{3}{*}{700} & 100 & 7.93 & 10.51 & 1.45 & 11.96 & 56 & 4804 & 0.14 & 3.87 & 2.00 \\
\hline & 200 & 15.41 & 22.78 & 4.56 & 27.34 & 77.5 & 6443 & 0.20 & 4.81 & 3.48 \\
\hline & 400 & 23.55 & 36.79 & 8.79 & 45.58 & 83.3 & 4233 & 0.24 & 5.38 & 5.01 \\
\hline \multicolumn{11}{|c|}{ Significance } \\
\hline \multicolumn{2}{|c|}{ Genotype (G) } & $* *$ & ** & $* *$ & ** & $* *$ & NS & $* *$ & $* *$ & $* *$ \\
\hline \multicolumn{2}{|c|}{$\left[\mathrm{CO}_{2}\right](\mathrm{C})$} & $* *$ & $* *$ & $* *$ & $* *$ & $* *$ & NS & NS & $* *$ & $* *$ \\
\hline \multicolumn{2}{|c|}{ PPFD (P) } & $* *$ & $* *$ & $* *$ & $* *$ & $* *$ & NS & NS & $* *$ & ** \\
\hline \multicolumn{2}{|c|}{$\mathrm{LSD}_{0.05}$} & 6.19 & 9.33 & 2.43 & 11.16 & 24.9 & 897 & 0.09 & 0.62 & 1.26 \\
\hline
\end{tabular}

*, **Significant at 0.05 and 0.01 levels of probability, respectively. NS = Not significant. 
Table 2. The effect of $\left[\mathrm{CO}_{2}\right]$ and photosynthetic photon flux density (PPFD) on leaf parameters of three cacao genotypes.

\begin{tabular}{|c|c|c|c|c|c|c|}
\hline $\begin{array}{c}{\left[\mathrm{CO}_{2}\right]} \\
\left(\mu \mathrm{mol} \cdot \mathrm{mol}^{-1}\right)\end{array}$ & $\begin{array}{c}\text { PPFD } \\
\left(\mu \mathrm{mol} \cdot \mathrm{m}^{-2} \cdot \mathrm{s}^{-1}\right)\end{array}$ & $\begin{array}{l}\text { Leaf Area } \\
\left(\mathrm{cm}^{2} / \text { plant }\right)\end{array}$ & $\begin{array}{c}\text { Specific } \\
\text { Leaf Area } \\
\left(\mathrm{cm}^{2} \cdot \mathrm{g}^{-1}\right)\end{array}$ & $\begin{array}{c}\text { Leaf Mass/ } \\
\text { Unit Area } \\
\left(\mathrm{g} \cdot \mathrm{cm}^{-2} \times 10^{-3}\right)\end{array}$ & $\begin{array}{l}\text { Leaf/ } \\
\text { Shoot } \\
\text { Ratio }\end{array}$ & $\begin{array}{c}\text { Leaf Area } \\
\text { Ratio } \\
\left(\mathrm{cm}^{2} \cdot \mathrm{g}^{-1}\right)\end{array}$ \\
\hline \multicolumn{7}{|l|}{ CCN 51} \\
\hline \multirow[t]{3}{*}{400} & 100 & 2143.2 & 362.7 & 2.77 & 0.77 & 230.5 \\
\hline & 200 & 2163.0 & 329.1 & 3.05 & 0.75 & 206.7 \\
\hline & 400 & 4783.2 & 285.4 & 3.52 & 0.79 & 187.4 \\
\hline \multirow[t]{3}{*}{700} & 100 & 2682.8 & 363.7 & 2.75 & 0.78 & 230.0 \\
\hline & 200 & 3437.7 & 298.3 & 3.37 & 0.76 & 191.8 \\
\hline & 400 & 5350.3 & 233.7 & 4.29 & 0.70 & 133.8 \\
\hline \multicolumn{7}{|l|}{ VB 1117} \\
\hline \multirow[t]{3}{*}{400} & 100 & 1974.1 & 286.2 & 3.50 & 0.77 & 191.6 \\
\hline & 200 & 2416.0 & 223.0 & 4.55 & 0.72 & 138.3 \\
\hline & 400 & 2685.3 & 204.7 & 4.91 & 0.68 & 123.9 \\
\hline \multirow[t]{3}{*}{700} & 100 & 3079.0 & 270.5 & 3.70 & 0.71 & 173.4 \\
\hline & 200 & 4040.9 & 241.8 & 4.16 & 0.69 & 149.2 \\
\hline & 400 & 5173.2 & 228.9 & 4.41 & 0.65 & 130.0 \\
\hline \multicolumn{7}{|l|}{ NO 81} \\
\hline \multirow[t]{3}{*}{400} & 100 & 2356.4 & 314.2 & 3.19 & 0.78 & 210.5 \\
\hline & 200 & 3113.7 & 270.3 & 3.75 & 0.77 & 184.0 \\
\hline & 400 & 4626.8 & 211.3 & 4.76 & 0.76 & 139.9 \\
\hline \multirow[t]{3}{*}{700} & 100 & 2342.7 & 302.5 & 3.37 & 0.75 & 198.7 \\
\hline & 200 & 3904.7 & 250.1 & 4.03 & 0.67 & 140.7 \\
\hline & 400 & 5004.6 & 212.2 & 4.77 & 0.64 & 110.7 \\
\hline \multicolumn{7}{|l|}{ Significance } \\
\hline Genotype (G) & & NS & ** & $* *$ & $* *$ & $* *$ \\
\hline$\left[\mathrm{CO}_{2}\right](\mathrm{C})$ & & $* *$ & NS & $* *$ & $* *$ & $* *$ \\
\hline PPFD (P) & & $* *$ & $* *$ & NS & $* *$ & $* *$ \\
\hline $\mathrm{LSD}_{0.05}$ & & 1694 & 65.2 & 1.01 & 0.10 & 50.2 \\
\hline
\end{tabular}

*, **Significant at 0.05 and 0.01 levels of probability, respectively. NS $=$ Not significant.

area, compared to plants grown under the ambient averaged $\left[\mathrm{CO}_{2}\right]$ of 400 $\mu \mathrm{mol} \cdot \mathrm{mol}^{-1}$.

In the present study at both $\left[\mathrm{CO}_{2}\right]$ in all the genotypes, increasing PPFD from 100 to $400 \mu \mathrm{mol} \cdot \mathrm{m}^{-2} \cdot \mathrm{s}^{-1}$ increased growth parameters and the effects were significant for leaf, shoot and root biomass accumulation, stem height, leaf parameters, RGR and NAR, however PPFD effects were non-significant for root/shoot ratio, total root length and leaf mass/unit area. At both $\left[\mathrm{CO}_{2}\right]$ in all the genotypes, increasing PPFD from 100 to $400 \mu \mathrm{mol} \cdot \mathrm{m}^{-2} \cdot \mathrm{s}^{-1}$ significantly increased leaf 
area and decreased SLA and LAR. This is a reflection of increased leaf and shoots plus root biomass with increasing PPFD. Baligar et al. [40] reported similar response in cacao leaf parameters by increasing PPFD from 65 to 1050 $\mu \mathrm{mol} \cdot \mathrm{m}^{-2} \cdot \mathrm{s}^{-1}$ and such response was observed in plants grown at $\left[\mathrm{CO}_{2}\right]$ of 330 and $700 \mu \mathrm{mol} \cdot \mathrm{mol}^{-1}$. However, the higher PPFD of $1050 \mu \mathrm{mol} \cdot \mathrm{m}^{-2} \cdot \mathrm{s}^{-1}$ was detrimental to the growth of cacao. Cacao genotypic variation in leaf production, leaf area and stem dry weight in response to light levels has been reported [38] [40] [41]. Van de Geijin and Dijkstra [50] stated that a complex interaction exists between plant nutrition, light level, daylength and growth enhancement by elevated $\left[\mathrm{CO}_{2}\right]$.

\section{2. $\left[\mathrm{CO}_{2}\right]$ and PPFD Effects on Mineral Nutrient Uptake and Use Efficiency}

\subsubsection{Mineral Concentration and Uptake}

Irrespective of $\left[\mathrm{CO}_{2}\right]$ and PPFD, invariably genotypes differed significantly in plant concentrations of all the essential macro-micro nutrients (Table 3). With the exception of B and $\mathrm{Zn}$ concentrations, overall CCN 51 in comparisons to other two genotypes had the highest concentration of all the nutrients. With the exception of $\mathrm{Fe}$, irrespective of PPFD, increasing $\left[\mathrm{CO}_{2}\right]$ from 400 to 700 $\mu \mathrm{mol} \cdot \mathrm{mol}^{-1}$ decreased concentrations of all the nutrients, however the effect of $\left[\mathrm{CO}_{2}\right]$ was only significant for $\mathrm{N}, \mathrm{K}, \mathrm{Ca}, \mathrm{B}, \mathrm{Cu}, \mathrm{Mn}$ and $\mathrm{Zn}$ concentrations. Irrespective of $\left[\mathrm{CO}_{2}\right]$, increasing PPFD from 100 to $400 \mu \mathrm{mol} \cdot \mathrm{m}^{-2} \cdot \mathrm{s}^{-1}$ decreased concentrations of all nutrients and this is a reflection of an increase in shoot dry matter with increasing PPFD. Concentrations of $\mathrm{P}$ and $\mathrm{Mg}$ were slightly higher but concentrations of other macro and micronutrients observed were comparable to concentrations reported in the literature [70] [71] [72].

Genotypes, irrespective of $\left[\mathrm{CO}_{2}\right]$ and PPFD, invariably differed significantly for up-take of all the essential macro-micro nutrients (Table 4). With exception of K, NO 81 genotype accumulated highest amount of all the nutrients, and this is reflection of its ability to accumulate highest amount of shoot dry matter compared to other genotypes. Irrespective of PPFD, increasing $\left[\mathrm{CO}_{2}\right]$ from 400 to $700 \mu \mathrm{mol} \cdot \mathrm{mol}^{-1}$ increased the uptake of all the nutrients; however, the effect was significant only for uptake of $\mathrm{P}, \mathrm{K}, \mathrm{Ca}, \mathrm{Mg}$, $\mathrm{Cu}$, and Fe. Baligar et al. [40] reported that in cacao genotype comum increasing $\left[\mathrm{CO}_{2}\right]$ from 380 to $700 \mu \mathrm{mol} \cdot \mathrm{mol}^{-1}$ increased uptake of all essential nutrients and further they stated that increased nutrient uptake at higher $\left[\mathrm{CO}_{2}\right]$ is due to increased demand for mineral nutrients due to enhanced dry matter accumulations. In a recent study with seven cacao genotypes Baligar et al. [43] reported that increasing $\left[\mathrm{CO}_{2}\right]$ from 400 to $700 \mu \mathrm{mol} \cdot \mathrm{mol}^{-1}$ significantly increased the uptake macro-micronutrients. In the current study irrespective of $\left[\mathrm{CO}_{2}\right]$ increasing PPFD from 100 to $400 \mu \mathrm{mol} \cdot \mathrm{m}^{-2} \cdot \mathrm{s}^{-1}$ significantly increased uptake of all the nutrients. The overall nutrient accumulation was in the order of $\mathrm{N}>\mathrm{K}=\mathrm{Ca}>\mathrm{Mg}>\mathrm{P}$ for macro nutrients and $\mathrm{Mn}>\mathrm{Zn}>\mathrm{B}>$ $\mathrm{Fe}>\mathrm{Cu}$ for micronutrients. 
Table 3. The effect of $\left[\mathrm{CO}_{2}\right]$ and photosynthetic photon flux density (PPFD) on mineral nutrient concentrations of three cacao genotypes.

\begin{tabular}{|c|c|c|c|c|c|c|c|c|c|c|c|}
\hline \multirow{2}{*}{$\begin{array}{c}{\left[\mathrm{CO}_{2}\right]} \\
\left(\mu \mathrm{mol} \cdot \mathrm{mol}^{-1}\right)\end{array}$} & \multirow{2}{*}{$\begin{array}{c}\text { PPFD } \\
\left(\mu \mathrm{mol} \cdot \mathrm{m}^{-2} \cdot \mathrm{s}^{-1}\right)\end{array}$} & $\mathbf{N}$ & $\mathbf{P}$ & $\mathrm{K}$ & $\mathrm{Ca}$ & $\mathrm{Mg}$ & B & $\mathrm{Cu}$ & $\mathrm{Fe}$ & $\mathrm{Mn}$ & $\mathrm{Zn}$ \\
\hline & & \multicolumn{5}{|c|}{$\mathrm{mg} \cdot \mathrm{g}^{-1}$} & \multicolumn{5}{|c|}{$\mu \mathrm{g} \cdot \mathrm{g}^{-1}$} \\
\hline & & \multicolumn{10}{|c|}{ CCN 51} \\
\hline \multirow[t]{3}{*}{400} & 100 & 23.3 & 4.2 & 20.4 & 17.2 & 7.2 & 41.1 & 15.3 & 28.0 & 88.6 & 35.7 \\
\hline & 200 & 24.2 & 4.5 & 18.4 & 18.0 & 7.0 & 41.4 & 17.5 & 20.2 & 118.5 & 32.0 \\
\hline & 400 & 20.3 & 4.1 & 16.3 & 18.4 & 7.9 & 32.0 & 17.1 & 28.7 & 61.1 & 30.6 \\
\hline \multirow[t]{4}{*}{700} & 100 & 22.2 & 4.4 & 21.1 & 17.9 & 6.2 & 36.7 & 19.4 & 27.2 & 91.5 & 36.2 \\
\hline & 200 & 20.0 & 4.3 & 19.0 & 17.8 & 7.9 & 33.3 & 18.9 & 26.1 & 100.6 & 36.9 \\
\hline & 400 & 12.6 & 3.8 & 12.6 & 14.7 & 7.3 & 16.0 & 11.1 & 31.8 & 36.3 & 20.9 \\
\hline & & \multicolumn{10}{|c|}{ VB 1117} \\
\hline \multirow[t]{3}{*}{400} & 100 & 21.6 & 3.2 & 20.2 & 11.8 & 7.1 & 46.7 & 12.7 & 20.9 & 139.4 & 54.0 \\
\hline & 200 & 22.1 & 3.5 & 19.0 & 17.1 & 7.1 & 38.6 & 16.1 & 23.7 & 97.8 & 39.1 \\
\hline & 400 & 20.6 & 3.2 & 17.8 & 15.3 & 6.5 & 29.9 & 13.4 & 23.6 & 82.5 & 35.2 \\
\hline \multirow[t]{4}{*}{700} & 100 & 19.7 & 3.3 & 20.2 & 14.8 & 6.4 & 36.3 & 14.4 & 26.9 & 78.0 & 33.1 \\
\hline & 200 & 15.8 & 3.7 & 15.5 & 13.9 & 6.5 & 23.3 & 13.7 & 21.3 & 46.9 & 21.2 \\
\hline & 400 & 12.8 & 3.6 & 13.2 & 12.6 & 5.9 & 14.4 & 10.4 & 21.3 & 37.0 & 21.7 \\
\hline & & \multicolumn{10}{|c|}{ NO 81} \\
\hline \multirow[t]{3}{*}{400} & 100 & 21.6 & 4.1 & 19.2 & 18.9 & 6.6 & 42.5 & 16.7 & 23.0 & 121.6 & 52.4 \\
\hline & 200 & 21.0 & 4.3 & 16.3 & 18.3 & 6.1 & 34.2 & 14.6 & 24.2 & 90.2 & 38.7 \\
\hline & 400 & 18.6 & 4.0 & 13.1 & 19.6 & 7.2 & 27.1 & 15.2 & 22.0 & 76.5 & 39.5 \\
\hline \multirow[t]{3}{*}{700} & 100 & 20.6 & 4.1 & 19.7 & 12.2 & 6.5 & 39.8 & 13.2 & 21.5 & 87.2 & 48.4 \\
\hline & 200 & 15.1 & 4.3 & 15.6 & 18.0 & 7.3 & 26.1 & 14.1 & 28.5 & 60.2 & 33.1 \\
\hline & 400 & 12.4 & 3.9 & 12.9 & 16.2 & 7.6 & 42.6 & 13.2 & 38.2 & 40.2 & 28.7 \\
\hline \multicolumn{12}{|l|}{ Significance } \\
\hline Genotype (G) & & $* *$ & $* *$ & $* *$ & $* *$ & * & NS & ** & NS & NS & $* *$ \\
\hline$\left[\mathrm{CO}_{2}\right](\mathrm{C})$ & & $* *$ & NS & $* *$ & * & NS & * & NS & * & $* *$ & $* *$ \\
\hline PPFD (P) & & $* *$ & NS & ** & NS & NS & $* *$ & ** & NS & $* *$ & $* *$ \\
\hline $\mathrm{LSD}_{0.05}$ & & 5.4 & 1.3 & 4.0 & 7.7 & 2.0 & 36.9 & 6.7 & 16.0 & 63.2 & 20.9 \\
\hline
\end{tabular}

*, **Significant at 0.05 and 0.01 levels of probability, respectively. NS $=$ Not significant.

\subsubsection{Mineral Nutrient Influx (IN) and Transport (TR)}

In South-Central America cacao is invariably grown on infertile soils under high temperatures and light intensities with lower soil moisture. Such climatic conditions might have major effects on plants ability to acquire (IN) and transport (TR) essential nutrients. However, very limited information is available on how increasing $\left[\mathrm{CO}_{2}\right]$ and PPFD affect macro-micronutrients IN and TR. In the current study, with the exception of IN for $\mathrm{Mn}$, at all $\left[\mathrm{CO}_{2}\right]$ and PPFD, genotypes differed significantly for IN of all macro-micro nutrients (Table 5). Irrespective 
Table 4. The effect of $\left[\mathrm{CO}_{2}\right]$ and photosynthetic photon flux density (PPFD) on mineral nutrient uptake of three cacao genotypes.

\begin{tabular}{|c|c|c|c|c|c|c|c|c|c|c|c|}
\hline \multirow{2}{*}{$\begin{array}{c}{\left[\mathrm{CO}_{2}\right]} \\
\left(\mu \mathrm{mol} \cdot \mathrm{mol}^{-1}\right)\end{array}$} & \multirow{2}{*}{$\begin{array}{c}\text { PPFD } \\
\left(\mu \mathrm{mol} \cdot \mathrm{m}^{-2} \cdot \mathrm{s}^{-1}\right)\end{array}$} & $\mathbf{N}$ & $\mathbf{P}$ & $\mathrm{K}$ & $\mathrm{Ca}$ & $\mathrm{Mg}$ & B & $\mathrm{Cu}$ & $\mathrm{Fe}$ & Mn & $\mathrm{Zn}$ \\
\hline & & \multicolumn{5}{|c|}{$\mathrm{mg} /$ plant } & \multicolumn{5}{|c|}{$\mu g /$ plant } \\
\hline & \multicolumn{11}{|c|}{ CCN51 } \\
\hline \multirow[t]{3}{*}{400} & 100 & 179.6 & 32.6 & 156.3 & 131.2 & 55.5 & 305.6 & 117.6 & 211.7 & 662.2 & 281.4 \\
\hline & 200 & 209.1 & 38.6 & 159.7 & 155.5 & 60.2 & 358.7 & 151.8 & 175.6 & 1030.8 & 279.7 \\
\hline & 400 & 441.3 & 87.2 & 344.9 & 395.0 & 163.9 & 669.3 & 368.7 & 609.7 & 1361.4 & 660.3 \\
\hline \multirow[t]{4}{*}{700} & 100 & 212.5 & 42.3 & 200.2 & 169.8 & 59.2 & 345.6 & 184.2 & 255.9 & 868.0 & 337.9 \\
\hline & 200 & 304.5 & 65.2 & 286.9 & 272.3 & 121.9 & 497.9 & 286.6 & 410.9 & 1491.5 & 560.1 \\
\hline & 400 & 403.6 & 123.3 & 411.5 & 480.5 & 239.1 & 519.1 & 369.1 & 1058.9 & 1165.5 & 691.9 \\
\hline & \multicolumn{11}{|c|}{ VB 1117} \\
\hline \multirow[t]{3}{*}{400} & 100 & 195.0 & 29.3 & 182.7 & 98.0 & 64.6 & 424.4 & 110.3 & 186.2 & 1200.4 & 468.4 \\
\hline & 200 & 338.7 & 53.4 & 289.4 & 260.0 & 107.6 & 588.0 & 246.6 & 365.7 & 1504.9 & 592.7 \\
\hline & 400 & 400.4 & 62.2 & 340.9 & 299.2 & 126.6 & 558.7 & 256.3 & 469.1 & 1575.9 & 683.5 \\
\hline \multirow[t]{4}{*}{700} & 100 & 312.8 & 53.1 & 320.7 & 236.3 & 101.9 & 577.3 & 230.2 & 426.8 & 1230.8 & 528.7 \\
\hline & 200 & 383.3 & 88.7 & 376.9 & 334.0 & 157.0 & 562.7 & 330.9 & 511.1 & 1146.5 & 512.9 \\
\hline & 400 & 439.6 & 128.0 & 459.3 & 440.0 & 210.1 & 494.1 & 365.4 & 767.8 & 1257.5 & 758.1 \\
\hline & \multicolumn{11}{|c|}{ NO 81} \\
\hline \multirow[t]{3}{*}{400} & 100 & 205.8 & 38.4 & 184.2 & 179.3 & 63.2 & 407.9 & 158.0 & 217.3 & 1122.2 & 496.9 \\
\hline & 200 & 306.6 & 63.6 & 241.2 & 268.2 & 90.1 & 477.8 & 215.9 & 361.3 & 1278.4 & 581.0 \\
\hline & 400 & 534.6 & 117.5 & 377.2 & 566.8 & 210.4 & 766.9 & 439.1 & 653.0 & 2127.9 & 1115.2 \\
\hline \multirow[t]{3}{*}{700} & 100 & 215.8 & 42.3 & 204.5 & 126.9 & 68.1 & 412.6 & 139.1 & 223.8 & 912.2 & 498.6 \\
\hline & 200 & 344.1 & 98.3 & 354.5 & 413.4 & 166.4 & 591.6 & 322.5 & 663.7 & 1367.0 & 758.0 \\
\hline & 400 & 451.0 & 143.5 & 471.5 & 589.5 & 278.8 & 1514.9 & 483.8 & 1392.3 & 1449.9 & 1046.7 \\
\hline \multicolumn{12}{|l|}{ Significance } \\
\hline Genotype (G) & & * & $* *$ & ** & ** & ** & NS & * & * & * & ** \\
\hline$\left[\mathrm{CO}_{2}\right](\mathrm{C})$ & & NS & $* *$ & $* *$ & $* *$ & $* *$ & NS & $* *$ & $* *$ & NS & NS \\
\hline PPFD (P) & & $* *$ & $* *$ & $* *$ & $* *$ & $* *$ & * & $* *$ & $* *$ & $* *$ & $* *$ \\
\hline $\mathrm{LSD}_{0.05}$ & & 183.7 & 45.5 & 130.3 & 177.7 & 77.6 & 1235.8 & 170.4 & 486.9 & 1043.5 & 419.9 \\
\hline
\end{tabular}

*, ${ }^{*}$ Significant at 0.05 and 0.01 levels of probability, respectively. NS $=$ Not significant.

of PPFD, increasing $\left[\mathrm{CO}_{2}\right]$ from 400 to $700 \mu \mathrm{mol} \cdot \mathrm{mol}^{-1}$ increased IN for all the nutrients, however the effect was significant only for IN of $\mathrm{P}, \mathrm{K}, \mathrm{Ca}, \mathrm{Mg}, \mathrm{Cu}$, and Fe. Irrespective of $\left[\mathrm{CO}_{2}\right]$, increasing PPFD from 100 to $400 \mu \mathrm{mol} \cdot \mathrm{m}^{-2} \cdot \mathrm{s}^{-1}$ significantly increased IN of all nutrients. Baligar et al. [40] reported that increasing $\left[\mathrm{CO}_{2}\right]$ from 380 to $700 \mu \mathrm{mol} \cdot \mathrm{mol}^{-1}$ tended to increase IN in cacao for many of the essential nutrients; however, increasing PPFD from 65 to $1050 \mu \mathrm{mol} \cdot \mathrm{m}^{-2} \cdot \mathrm{s}^{-1}$ tended to decrease IN for $\mathrm{N}, \mathrm{K}, \mathrm{Ca}, \mathrm{Mg}, \mathrm{P}, \mathrm{S}, \mathrm{Cu}$ and $\mathrm{Fe}$.

At all $\left[\mathrm{CO}_{2}\right]$ and PPFD, genotypes differed significantly in TR of $\mathrm{P}, \mathrm{K}, \mathrm{Ca}$, and $\mathrm{Zn}$ (Table 6). The $\left[\mathrm{CO}_{2}\right]$ significantly affected TR of $\mathrm{N}, \mathrm{P}, \mathrm{Mg}, \mathrm{Fe}, \mathrm{Mn}$ and $\mathrm{Zn}$. 
However, with the exception of TR for $\mathrm{N}$ and $\mathrm{B}$, PPFD significantly affected TR for all the other mac-ro-micronutrients. Increasing $\left[\mathrm{CO}_{2}\right]$ increased TR for P, $\mathrm{K}$, $\mathrm{Mg}$ and Fe only, however increasing PPFD slightly increased TR for P, Ca, Mg and Fe. Earlier, Baligar et al. [40] reported that in cacao genotype comum increasing $\left[\mathrm{CO}_{2}\right]$ from 400 to $700 \mu \mathrm{mol} \cdot \mathrm{mol}^{-1}$ decreased TR for $\mathrm{N}, \mathrm{Ca}$, and $\mathrm{Zn}$ and increased TR for other elements. Such variations in IN and TR at varying $\left[\mathrm{CO}_{2}\right]$ and PPFD could be related to nature of genotypes and their interactions with $\left[\mathrm{CO}_{2}\right]$ and PPFD.

Table 5. The effect of $\left[\mathrm{CO}_{2}\right]$ and photosynthetic photon flux density (PPFD) on mineral nutrient influx by root length of three cacao genotypes.

\begin{tabular}{|c|c|c|c|c|c|c|c|c|c|c|c|}
\hline \multirow{2}{*}{$\begin{array}{c}{\left[\mathrm{CO}_{2}\right]} \\
\left(\mu \mathrm{mol} \cdot \mathrm{mol}^{-1}\right)\end{array}$} & \multirow{2}{*}{$\begin{array}{c}\text { PPFD } \\
\left(\mu \mathrm{mol} \cdot \mathrm{m}^{-2} \cdot \mathrm{s}^{-1}\right)\end{array}$} & $\mathrm{N}$ & $\mathbf{P}$ & K & $\mathrm{Ca}$ & $\mathrm{Mg}$ & B & $\mathrm{Cu}$ & $\mathrm{Fe}$ & $\mathrm{Mn}$ & $\mathrm{Zn}$ \\
\hline & & \multicolumn{5}{|c|}{$\mathrm{pmol} \mathrm{cm} \cdot \operatorname{root}^{-1} \cdot \mathrm{s}^{-1}$} & \multicolumn{5}{|c|}{$\mathrm{pmol} \mathrm{cm} \cdot \operatorname{root}^{-1} \cdot \mathrm{s}^{-1}\left(\times 10^{3}\right)$} \\
\hline & \multicolumn{11}{|c|}{ CCN 51} \\
\hline \multirow[t]{3}{*}{400} & 100 & 0.79 & 0.06 & 0.25 & 0.21 & 0.15 & 1.98 & 0.11 & 0.25 & 0.74 & 0.24 \\
\hline & 200 & 1.14 & 0.09 & 0.34 & 0.30 & 0.20 & 2.70 & 0.19 & 0.25 & 1.61 & 0.35 \\
\hline & 400 & 1.89 & 0.15 & 0.51 & 0.53 & 0.36 & 3.02 & 0.32 & 0.65 & 1.36 & 0.52 \\
\hline \multirow[t]{4}{*}{700} & 100 & 1.04 & 0.10 & 0.36 & 0.31 & 0.17 & 2.40 & 0.21 & 0.37 & 1.32 & 0.39 \\
\hline & 200 & 1.23 & 0.11 & 0.43 & 0.36 & 0.26 & 2.49 & 0.24 & 0.42 & 1.65 & 0.52 \\
\hline & 400 & 1.63 & 0.19 & 0.56 & 0.65 & 0.52 & 2.37 & 0.28 & 0.90 & 1.22 & 0.51 \\
\hline & \multicolumn{11}{|c|}{ VB 1117} \\
\hline \multirow[t]{3}{*}{400} & 100 & 1.30 & 0.09 & 0.45 & 0.20 & 0.26 & 3.92 & 0.13 & 0.32 & 1.84 & 0.66 \\
\hline & 200 & 1.56 & 0.11 & 0.50 & 0.44 & 0.31 & 3.74 & 0.26 & 0.39 & 1.71 & 0.64 \\
\hline & 400 & 1.85 & 0.13 & 0.55 & 0.50 & 0.34 & 3.71 & 0.26 & 0.52 & 1.95 & 0.72 \\
\hline \multirow[t]{4}{*}{700} & 100 & 1.48 & 0.11 & 0.55 & 0.38 & 0.27 & 3.57 & 0.23 & 0.53 & 1.70 & 0.51 \\
\hline & 200 & 1.70 & 0.19 & 0.57 & 0.53 & 0.40 & 3.27 & 0.28 & 0.58 & 1.27 & 0.51 \\
\hline & 400 & 2.23 & 0.31 & 0.88 & 0.82 & 0.69 & 3.42 & 0.42 & 1.07 & 1.43 & 0.77 \\
\hline & \multicolumn{11}{|c|}{ NO 81} \\
\hline \multirow[t]{3}{*}{400} & 100 & 0.93 & 0.08 & 0.30 & 0.31 & 0.16 & 2.31 & 0.17 & 0.26 & 1.56 & 0.55 \\
\hline & 200 & 1.57 & 0.16 & 0.46 & 0.50 & 0.29 & 3.02 & 0.24 & 0.45 & 1.30 & 0.66 \\
\hline & 400 & 2.30 & 0.20 & 0.58 & 0.79 & 0.46 & 4.09 & 0.37 & 0.62 & 2.15 & 0.92 \\
\hline \multirow[t]{3}{*}{700} & 100 & 1.25 & 0.11 & 0.40 & 0.27 & 0.23 & 3.07 & 0.16 & 0.29 & 1.30 & 0.67 \\
\hline & 200 & 1.37 & 0.14 & 0.50 & 0.52 & 0.34 & 3.01 & 0.26 & 0.48 & 1.54 & 0.70 \\
\hline & 400 & 2.29 & 0.35 & 0.89 & 1.17 & 0.89 & 4.01 & 0.57 & 2.26 & 1.91 & 1.15 \\
\hline \multicolumn{12}{|l|}{ Significance } \\
\hline Genotype (G) & & * & $* *$ & $* *$ & $* *$ & $* *$ & $* *$ & * & $* *$ & NS & $* *$ \\
\hline$\left[\mathrm{CO}_{2}\right](\mathrm{C})$ & & NS & ** & ** & ** & ** & NS & ** & ** & NS & NS \\
\hline PPFD (P) & & $* *$ & $* *$ & $* *$ & $* *$ & $* *$ & * & $* *$ & ** & NS & ** \\
\hline $\mathrm{LSD}_{0.05}$ & & 0.32 & 0.03 & 0.08 & 0.12 & 0.05 & 0.48 & 0.07 & 0.16 & 0.44 & 0.16 \\
\hline
\end{tabular}

${ }^{*},{ }^{*}$ Significant at 0.05 and 0.01 levels of probability, respectively. NS $=$ Not significant. 
Table 6. The effect of $\left[\mathrm{CO}_{2}\right]$ and photosynthetic photon flux density (PPFD) on mineral nutrient transport of three cacao genotypes.

\begin{tabular}{|c|c|c|c|c|c|c|c|c|c|c|c|}
\hline \multirow{2}{*}{$\begin{array}{c}{\left[\mathrm{CO}_{2}\right]} \\
\left(\mu \mathrm{mol} \cdot \mathrm{mol}^{-1}\right)\end{array}$} & \multirow{2}{*}{$\begin{array}{c}\text { PPFD } \\
\left(\mu \mathrm{mol} \cdot \mathrm{m}^{-2} \cdot \mathrm{s}^{-1}\right)\end{array}$} & $\mathbf{N}$ & $\mathbf{P}$ & $\mathrm{K}$ & $\mathrm{Ca}$ & $\mathrm{Mg}$ & B & $\mathrm{Cu}$ & $\mathrm{Fe}$ & $\mathrm{Mn}$ & $\mathrm{Zn}$ \\
\hline & & \multicolumn{10}{|c|}{$\mathrm{pmol} \mathrm{g} \cdot \mathrm{shoot}^{-1} \cdot \mathrm{s}^{-1}$} \\
\hline & & \multicolumn{10}{|c|}{ CCN 51} \\
\hline \multirow[t]{3}{*}{400} & 100 & 686.9 & 55.2 & 217.3 & 185.9 & 127.9 & 1.64 & 0.10 & 0.21 & 0.70 & 0.24 \\
\hline & 200 & 748.8 & 61.7 & 204.3 & 203.2 & 128.6 & 1.73 & 0.12 & 0.16 & 0.98 & 0.22 \\
\hline & 400 & 805.9 & 72.5 & 230.0 & 259.9 & 181.0 & 1.66 & 0.15 & 0.29 & 0.63 & 0.26 \\
\hline \multirow[t]{4}{*}{700} & 100 & 701.6 & 62.7 & 241.8 & 205.8 & 117.1 & 1.56 & 0.13 & 0.22 & 0.77 & 0.25 \\
\hline & 200 & 719.3 & 69.5 & 246.3 & 231.3 & 168.4 & 1.59 & 0.15 & 0.24 & 0.95 & 0.29 \\
\hline & 400 & 539.3 & 73.7 & 196.2 & 226.2 & 184.7 & 0.91 & 0.11 & 0.35 & 0.41 & 0.20 \\
\hline & & \multicolumn{10}{|c|}{ VB 1117} \\
\hline \multirow[t]{3}{*}{400} & 100 & 689.9 & 45.4 & 233.1 & 132.8 & 135.7 & 2.01 & 0.09 & 0.17 & 1.17 & 0.38 \\
\hline & 200 & 824.2 & 58.0 & 254.0 & 227.2 & 154.8 & 1.90 & 0.13 & 0.22 & 0.95 & 0.32 \\
\hline & 400 & 810.0 & 56.7 & 249.6 & 214.8 & 149.4 & 1.53 & 0.12 & 0.23 & 0.84 & 0.30 \\
\hline \multirow[t]{4}{*}{700} & 100 & 739.7 & 55.9 & 273.9 & 199.5 & 141.3 & 1.81 & 0.12 & 0.26 & 0.77 & 0.27 \\
\hline & 200 & 655.1 & 69.0 & 231.8 & 204.4 & 157.4 & 1.27 & 0.13 & 0.22 & 0.50 & 0.19 \\
\hline & 400 & 568.8 & 73.7 & 212.4 & 200.5 & 154.8 & 0.84 & 0.10 & 0.24 & 0.42 & 0.21 \\
\hline & & \multicolumn{10}{|c|}{ NO 81} \\
\hline \multirow[t]{3}{*}{400} & 100 & 683.0 & 57.0 & 218.5 & 216.1 & 124.3 & 1.80 & 0.12 & 0.18 & 1.01 & 0.37 \\
\hline & 200 & 742.4 & 68.3 & 206.7 & 232.5 & 127.3 & 1.57 & 0.11 & 0.22 & 0.83 & 0.30 \\
\hline & 400 & 781.6 & 76.5 & 195.7 & 291.7 & 177.4 & 1.48 & 0.14 & 0.23 & 0.82 & 0.36 \\
\hline \multirow[t]{3}{*}{700} & 100 & 663.5 & 58.5 & 228.4 & 140.5 & 124.4 & 1.71 & 0.09 & 0.17 & 0.74 & 0.35 \\
\hline & 200 & 597.2 & 76.6 & 221.8 & 255.8 & 169.7 & 1.36 & 0.12 & 0.29 & 0.62 & 0.29 \\
\hline & 400 & 545.0 & 78.6 & 204.0 & 253.1 & 196.9 & 2.46 & 0.13 & 0.43 & 0.46 & 0.27 \\
\hline \multicolumn{12}{|l|}{ Significance } \\
\hline Genotype (G) & & NS & $* *$ & $* *$ & $* *$ & NS & NS & NS & NS & NS & $* *$ \\
\hline$\left[\mathrm{CO}_{2}\right](\mathrm{C})$ & & $* *$ & $* *$ & NS & NS & * & NS & NS & $* *$ & $* *$ & $* *$ \\
\hline PPFD (P) & & NS & ** & ** & $* *$ & $* *$ & NS & $* *$ & ** & $* *$ & * \\
\hline $\mathrm{LSD}_{0.05}$ & & 238.8 & 24.8 & 56.4 & 95.8 & 50.0 & 2.08 & 0.06 & 0.16 & 0.56 & 0.16 \\
\hline
\end{tabular}

*,**Significant at 0.05 and 0.01 levels of probability, respectively. NS = Not significant.

\subsubsection{Mineral Nutrient Use Efficiency (NUE)}

Irrespective of $\left[\mathrm{CO}_{2}\right]$ and PPFD, VB 1117 genotype was very efficient in NUE of absorbed P, Ca, Mg, B, Cu, Fe, Mn, and Zn, whereas No 81 was efficient in use of absorbed $\mathrm{N}$ and $\mathrm{K}$ (Table 7). However genotypic effects were significant only for NUE of $\mathrm{P}, \mathrm{K}, \mathrm{Mg}$ and $\mathrm{Zn}$. In many crop cultivars, interspecific variation in NUE for macro and micro nutrients is well documented and such variations have been related to absorption, translocation, shoot demand, and dry matter production potentials per unit of nutrient absorbed [44] [73] [74] [75]. Irrespective of 
Table 7. The effect of $\left[\mathrm{CO}_{2}\right]$ and photosynthetic photon flux density (PPFD) on mineral nutrient use efficiency of three cacao genotypes.

\begin{tabular}{|c|c|c|c|c|c|c|c|c|c|c|c|}
\hline \multirow{2}{*}{$\begin{array}{c}{\left[\mathrm{CO}_{2}\right]} \\
\left(\mu \mathrm{mol} \cdot \mathrm{mol}^{-1}\right)\end{array}$} & \multirow{2}{*}{$\begin{array}{c}\text { PPFD } \\
\left(\mu \mathrm{mol} \cdot \mathrm{m}^{-2} \cdot \mathrm{s}^{-1}\right)\end{array}$} & $\mathrm{N}$ & $\mathbf{P}$ & $\mathrm{K}$ & $\mathrm{Ca}$ & $\mathrm{Mg}$ & B & $\mathrm{Cu}$ & $\mathrm{Fe}$ & $\mathrm{Mn}$ & $\mathrm{Zn}$ \\
\hline & & \multicolumn{5}{|c|}{ mg shoot mg element in shoot ${ }^{-1}$} & \multicolumn{5}{|c|}{ mg shoot mg element in shoot ${ }^{-1}\left(\times 10^{4}\right)$} \\
\hline & & & & & & $\mathrm{CCN}$ & & & & & \\
\hline \multirow[t]{3}{*}{400} & 100 & 43.0 & 239.2 & 49.2 & 58.3 & 139.7 & 2.49 & 6.58 & 3.65 & 1.15 & 2.83 \\
\hline & 200 & 41.3 & 224.9 & 54.7 & 56.3 & 143.7 & 2.42 & 5.73 & 5.04 & 0.85 & 3.23 \\
\hline & 400 & 50.8 & 247.2 & 61.6 & 55.4 & 130.5 & 3.25 & 5.98 & 3.53 & 2.40 & 3.51 \\
\hline \multirow[t]{4}{*}{700} & 100 & 45.1 & 227.1 & 47.6 & 56.4 & 160.8 & 2.77 & 5.25 & 4.15 & 1.15 & 2.83 \\
\hline & 200 & 50.1 & 238.7 & 53.0 & 56.3 & 129.8 & 3.04 & 5.32 & 3.94 & 1.02 & 2.78 \\
\hline & 400 & 83.5 & 268.4 & 79.4 & 68.3 & 137.7 & 6.37 & 9.04 & 3.17 & 3.02 & 4.82 \\
\hline & & \multicolumn{10}{|c|}{ VB 1117} \\
\hline \multirow[t]{3}{*}{400} & 100 & 46.3 & 309.8 & 49.6 & 166.8 & 140.7 & 2.15 & 10.95 & 4.82 & 0.75 & 1.93 \\
\hline & 200 & 45.3 & 291.1 & 52.8 & 59.0 & 142.2 & 2.60 & 6.24 & 4.27 & 1.05 & 2.59 \\
\hline & 400 & 48.8 & 313.5 & 57.2 & 65.3 & 154.1 & 3.46 & 7.58 & 4.26 & 1.28 & 2.85 \\
\hline \multirow[t]{4}{*}{700} & 100 & 51.2 & 304.9 & 50.0 & 67.5 & 156.5 & 2.77 & 6.93 & 4.06 & 1.36 & 3.07 \\
\hline & 200 & 63.8 & 276.5 & 64.7 & 72.6 & 154.7 & 4.31 & 7.57 & 4.79 & 2.16 & 4.75 \\
\hline & 400 & 82.1 & 278.0 & 76.4 & 80.2 & 170.4 & 7.14 & 9.71 & 4.78 & 2.93 & 4.74 \\
\hline & & \multicolumn{10}{|c|}{ NO 81} \\
\hline \multirow[t]{3}{*}{400} & 100 & 46.4 & 250.0 & 52.3 & 53.4 & 151.9 & 2.38 & 6.06 & 4.62 & 0.94 & 1.93 \\
\hline & 200 & 47.7 & 235.3 & 62.2 & 54.6 & 164.9 & 2.98 & 6.90 & 4.35 & 1.20 & 2.67 \\
\hline & 400 & 54.3 & 252.1 & 76.9 & 52.2 & 142.0 & 3.82 & 6.75 & 4.70 & 1.45 & 2.72 \\
\hline \multirow[t]{3}{*}{700} & 100 & 48.6 & 246.7 & 51.0 & 113.4 & 154.1 & 2.54 & 9.40 & 4.72 & 1.16 & 2.20 \\
\hline & 200 & 67.7 & 238.7 & 64.8 & 55.5 & 139.1 & 3.84 & 7.13 & 3.89 & 1.76 & 3.27 \\
\hline & 400 & 84.4 & 260.5 & 78.3 & 63.5 & 133.3 & 5.79 & 7.73 & 2.79 & 2.84 & 3.58 \\
\hline
\end{tabular}

Significance

Genotype $(G)$

$\left[\mathrm{CO}_{2}\right](\mathrm{C})$

PPFD (P)

$\operatorname{LSD}_{0.05}$

$\begin{array}{lccccccccc}\text { NS } & * * & * * & \text { NS } & * & \text { NS } & \text { NS } & \text { NS } & \text { NS } & * * \\ * * & \text { NS } & * * & \text { NS } & \text { NS } & * * & \text { NS } & \text { NS } & * * & * * \\ * * & \text { NS } & * * & \text { NS } & \text { NS } & * * & \text { NS } & \text { NS } & * * & * * \\ 25.4 & 88.7 & 14.9 & 126.4 & 39.3 & 2.68 & 7.01 & 2.44 & 1.72 & 1.58\end{array}$

*, ${ }^{*}$ Significant at 0.05 and 0.01 levels of probability, respectively. NS $=$ Not significant.

PPFD, increasing $\left[\mathrm{CO}_{2}\right]$ from 400 to $700 \mu \mathrm{mol} \cdot \mathrm{mol}^{-1}$ increased NUE for all the nutrients but the effects were significant only for NUE of N, K, B, Mn and Zn. Baligar et al. [40] report that increasing $\left[\mathrm{CO}_{2}\right]$ from 380 to $700 \mu \mathrm{mol} \cdot \mathrm{mol}^{-1}$ increased NUE for $\mathrm{N}, \mathrm{Mg}, \mathrm{Cu}, \mathrm{Mn}$ and $\mathrm{Zn}$ in cacao.

With the exceptions of $\mathrm{Ca}$ and $\mathrm{Mg}$, irrespective of $\left[\mathrm{CO}_{2}\right]$, increasing PPFD from 100 to $400 \mu \mathrm{mol} \cdot \mathrm{m}^{-2} \cdot \mathrm{s}^{-1}$ invariably increased NUE for other nutrients but the effect was significant only for NUE of N, K, B, Mn and Zn. Baligar et al. [43] 
reported that in seven genetically different cacao genotypes increasing PPFD from 100 to $400 \mu \mathrm{mol} \cdot \mathrm{m}^{-2} \cdot \mathrm{s}^{-1}$ and increasing $\left[\mathrm{CO}_{2}\right]$ from 380 to $700 \mu \mathrm{mol} \cdot \mathrm{mol}^{-1}$ increased NUE for all macro and micro nutrients. Generally, $\mathrm{C}_{3}$ plants respond positively to increased $\left[\mathrm{CO}_{2}\right.$ ] above $370 \mu \mathrm{mol} \cdot \mathrm{mol}^{-1}$ [65] [67] [68].

Loss of vegetative cover has increased light levels in cacao plantations and coupled with the anticipated increase in $\left[\mathrm{CO}_{2}\right]$ might alter the ability of cacao to utilize absorbed nutrients efficiently. Such changes might lead to higher fertilizer inputs to maintain yield potentials, thereby increasing the cost of cacao production. NUE values are useful in assessing the ability of cacao genotypes to use absorbed nutrients efficiently or non-efficiently. Such assessments are especially valuable in the identification of nutrient use efficient genotypes that are useful for degraded and low fertility tropical soils where adequate availability of essential nutrients is a constraint for growth and survivability of cacao. Cacao genotypes that have high NUE for essential nutrients under low PPFD, which is common for cacao grown under agroforestry systems, might be able to grow well and produce higher yields.

\section{Conclusion}

Cacao is invariably established as understory plant and is subjected to wide variations in light intensities depending upon nature and density of shade trees. Quality of light reaching cacao leaf canopy in greenhouse conditions is different than quality of light received by cacao grown under shade of upper story shade trees in field conditions. Therefore, the following conclusions are based on juvenile cacao genotypes subjected to ambient and elevated levels of $\left[\mathrm{CO}_{2}\right]$ at low to adequate levels of PPFD under greenhouse conditions. Intraspecific variations were observed in cacao genotypes for growth and nutrient uptake and use efficiency traits at varying levels of $\left[\mathrm{CO}_{2}\right]$ and PPFD. Increasing levels of $\left[\mathrm{CO}_{2}\right]$ and adequate PPFD are beneficial in improving cacao growth and mineral nutrient uptake and use efficiency. Overall, NO 81 genotype had a higher value for all the growth parameters and VB 1117 genotype was most efficient in nutrient use as compared to other two genotypes. Such information might be useful in identification of cacao genotypes suitable for heavy shaded cacao agroforestry or open canopy cacao cultivation systems.

\section{Acknowledgements}

We thank Dr. Regina C.R. Machado and Dr. Martin Aitken, former research scientists of MARS Center for Cocoa Science (MCCS), Alimirante, Itajuipe, Bahia, Brazil for providing pods of different cacao genotypes for this research and Shaun Faulkner for technical assistance. The support and advice of Dr. James Bunce in this research are greatly appreciated.

\section{Conflicts of Interest}

The authors declare no conflicts of interest regarding the publication of this pa- 
per.

\section{References}

[1] Galyuon, I.K.A., McDavid, C.R., Lopez, F.B. and Spence, J.A. (1996) The Effect of Irradiance Level on Cocoa (Theobroma cacao L.): I. Growth and Leaf Adaptations. Tropical Agriculture (Trinidad), 73, 23-28.

[2] Serrano, P. and Biehl, B. (1999) The Effect of Light Luminous Stress on the Cocoa Plant: Fluorometric Measurements under Experimental (Laboratory) Conditions and in the Field. In: Proceedings of the 12th International Cocoa Research Conference, Salvador, Cocoa Producers' Alliance, Lagos, Nigeria, 581-588.

[3] Mielke, M.S., Almeida, A.-A.F. and Gomes, F.P. (2005) Photosynthetic Traits of Five Neotropical Rainforest Tree Species: Interactions between Light Response Curves and Leaf-to-Air Vapour Pressure Deficit. Brazilian Archives of Biology and Technology, 48, 815-824. https://doi.org/10.1590/S1516-89132005000600018

[4] Daymond, A.J., Tricker, P.J. and Hadley, P. (2011) Genotypic Variation in Photosynthesis in Cacao Is Correlated with Stomatal Conductance and Leaf Nitrogen. Biologia Plantarum, 55, 99-104. https://doi.org/10.1007/s10535-011-0013-y

[5] Cunningham, R.K. and Burridge, J.C. (1960) The Growth of Cacao (Theobroma cacao) with and without Shade. Annals of Botany, 24, 458-462.

https://doi.org/10.1093/oxfordjournals.aob.a083718

[6] Beer, J., Muschler, R., Kass, D. and Somarriba, E. (1997) Shade Management in Coffee and Cacao Plantations. Agroforestry Systems, 38, 139-164.

https://doi.org/10.1023/A:1005956528316

[7] Zuidema, P.A., Leffelaar, P.A., Gerritsma, W., Mommer, L. and Anten, N.P.R. (2005) A Physiological Production Model for Cocoa (Theobroma cacao): Model Presentation, Validation and Application. Agricultural Systems, 84, 195-225. https://doi.org/10.1016/j.agsy.2004.06.015

[8] Gattward, J.N. and Almeida, A.-A.F. (2018) Cacao Tree Responses to Variation in Water Availability. In: Souza Júnior, J.O., Ed., Cocoa: Cultivation, Research and Innovation, EDITUS Publ., Ilhéus, 59-84.

[9] Willson K. (1999) Coffee, Cocoa and Tea. CABI Publishing, Wallingford, UK.

[10] Wood, G.A.R. and Lass, R.A. (2001) Cocoa. 4th Edition, Blackwell Science, Oxford. https://doi.org/10.1002/9780470698983

[11] de Almeida, A.-A.F. and Valle, R.R. (2007) Ecophysiology of the Cacao Tree. Brazilian Journal of Plant Physiology, 19, 425-448. https://doi.org/10.1590/S1677-04202007000400011

[12] Lahive, F., Hadley, P. and Daymond, A.J. (2019) The Physiological Responses of Cacao to the Environment and the Implications for Climate Change Resilience. A Review. Agronomy for Sustainable Development, 39, Article No. 5. https://doi.org/10.1007/s13593-018-0552-0

[13] Rice, R.A. and Greenberg, R. (2000) Cacao Cultivation and the Conservation of Biological Diversity. AMBIO: A Journal of the Human Environment, 29, 167-173. https://doi.org/10.1579/0044-7447-29.3.167

[14] Tscharntke, T., Clough, Y., Bhagwat, S.A., Buchori, D., Faust, H., Hertel, D., Hölscher, D., Juhrbandt, J., Kessler, M., Perfecto, I., Scherber, C., Schroth, G., Veldkamp, E. and Wanger, T.C. (2011) Multifunctional Shade-Tree Management in Tropical Agroforestry Landscapes-A Review. Journal of Applied Ecology, 48, 619-629. https://doi.org/10.1111/j.1365-2664.2010.01939.x 
[15] Sambuichi, R.H.R., Vidal, D.B., Piasentin, F.B., Jardim, J.G., Viana, T.G., Menezes, A.A., Mello, D.L.N., Ahnert, D. and Baligar, V.C. (2012) Cabruca Agroforests in Southern Bahia, Brazil: Tree Component, Management Practices and Tree Species Conservation. Biodiversity and Conservation, 21, 1055-1077. https://doi.org/10.1007/s10531-012-0240-3

[16] Acheampong, K., Hadley, P. and Daymond, A.J. (2013) Photosynthetic Activity and Early Growth of Four Cacao Genotypes as Influenced by Different Shade Regimes under West African Dry and Wet Season Conditions. Experimental Agriculture, 49, 31-42. https://doi.org/10.1017/S0014479712001007

[17] Saj, S., Durot, C., Mvondo Sakouma, K., Tayo Gamo, K. and Avana-Tientcheu, M.-L. (2017) Contribution of Associated Trees to Long-Term Species Conservation, Carbon Storage and Sustainability: A Functional Analysis of Tree Communities in Cacao Plantations of Central Cameroon. International Journal of Agricultural Sus tainability, 15, 282-302. https://doi.org/10.1080/14735903.2017.1311764

[18] Jagoret, P., Ngnogue, H.T., Malézieux, E. and Michel, I. (2018) Trajectories of Cocoa Agroforests and Their Drivers over Time: Lessons from the Cameroonian Experience. European Journal of Agronomy, 101, 183-192.

https://doi.org/10.1016/j.eja.2018.09.007

[19] Nijmeijer, A., Lauri, P.-E., Harmand, J.-M., Freschet, G.T., Essobo Nieboukaho, J.-D., Fogang, P.K., Enock, S. and Saj, S. (2019) Long-Term Dynamics of Cocoa Agroforestry Systems Established on Lands Previously Occupied by Savannah or Forests. Agriculture, Ecosystems \& Environment, 275, 100-111. https://doi.org/10.1016/j.agee.2019.02.004

[20] Abdulai, I., Jassogne, L., Graefe, S., Asare, R., Van Asten, P., Läderach, P. and Vaast, P. (2018) Characterization of Cocoa Production, Income Diversification and Shade Tree Management along a Climate Gradient in Ghana. PLoS ONE, 13, e0195777. https://doi.org/10.1371/journal.pone.0195777

[21] Niether, W., Armengot, L., Andres, C., Schneider, M. and Gerold, G. (2018) Shade Trees and Tree Pruning alter Throughfall and Microclimate in Cocoa (Theobroma cacao L.) Production Systems. Annals of Forest Science, 75, Article No. 38. https://doi.org/10.1007/s13595-018-0723-9

[22] Blaser, W.J., Oppong, J., Hart, S.P., Landolt, J., Yeboah, E. and Six, J. (2018) Climate-Smart Sustainable Agriculture in Low-to-Intermediate Shade Agroforests. Nature Sustainability, 1, 234-239. https://doi.org/10.1038/s41893-018-0062-8

[23] Asare, R., Markussen, B., Asare, R.A., Anim-Kwapong, G. and Ræbild, A. (2019) On-Farm Cocoa Yields Increase with Canopy Cover of Shade Trees in Two Agro-Ecological Zones in Ghana. Climate and Development, 11, 435-445. https://doi.org/10.1080/17565529.2018.1442805

[24] Schroth, G., Krauss, U., Gasparotto, L., Duarte Aguilar, J.A. and Vohland, K. (2000) Pests and Diseases in Agroforestry Systems of the Humid Tropics. Agroforestry Systems, 50, 199-241. https://doi.org/10.1023/A:1006468103914

[25] Raja Harun, R.M. and Kamariah, H. (1983) The Effects of Shading Regimes on the Growth of Cocoa Seedlings (Theobroma cacao L.). Pertunika, 6, 15.

[26] Suárez Salazar, J.C., Melgarejo, L.M., Casanoves, F., Di Rienzo, J.A., DaMatta, F.M. and Armas, C. (2018) Photosynthesis Limitations in Cacao Leaves under Different Agroforestry Systems in the Colombian Amazon. PLoS ONE, 13, e0206149. https://doi.org/10.1371/journal.pone.0206149

[27] Gommers, M.M., Visser, E.J.W., St. Onge, K.R., Voesenek, L.A.C.J. and Pierik, R. (2013) Shade Tolerance: When Growing Tall Is Not an Option. Trends in Plant 
Science, 18, 65-71. https://doi.org/10.1016/j.tplants.2012.09.008

[28] Fiorucci, A.-S. and Fankhauser, C. (2017) Plant Strategies for Enhancing Access to Sunlight-Review. Current Biology, 27, R931-R940.

https://doi.org/10.1016/j.cub.2017.05.085

[29] Blaser, W.J., Oppong, J., Yeboah, E. and Six, J. (2017) Shade Trees Have Limited Benefits for Soil Fertility in Cocoa Agroforests. Agriculture, Ecosystems \& Environment, 243, 83-91. https://doi.org/10.1016/j.agee.2017.04.007

[30] Okali, D.U.U. and Owusu, J.K. (1975) Growth Analysis and Photosynthetic Rates of Cocoa ( Theobroma cacao) Seedlings in Relation to Varying Shade and Nutrient Regimes. Ghana Journal of Agricultural Science, 8, 51-67.

[31] Hartemink, A.E. (2005) Nutrient Stocks, Nutrient Cycling, and Soil Changes in Cocoa Ecosystems: A Review. Advances in Agronomy, 86, 227-253. https://doi.org/10.1016/S0065-2113(05)86005-5

[32] Miyaji, K.-I., Da Silva, W.S. and De Paulo, T.A. (1997) Longevity of Leaves of a Tropical Tree, Theobroma cacao, Grown under Shading, in Relation to Position within the Canopy and Time of Emergence. New Phytologist, 135, 445-454. https://doi.org/10.1046/j.1469-8137.1997.00667.x

[33] Hutcheon, W.V. (1976) Photosynthesis of Cocoa: Photosynthesis in Relation to the Light and Plant Nutrient Status. Report of the Cocoa Research Institute of Ghana, 1973-74, 186-188.

[34] Raja Harun, R.M. and Hardwick, K. (1988) The Effects of Prolonged Exposure to Different Light Intensities on the Photosynthesis of Cocoa Leaves. In: Proceedings of the 10 th International Cocoa Research Conference, Santo Domingo, Cocoa Producers' Alliance, Lagos, Nigeria, 205-209.

[35] Bastid, P. and Jimmy I. (2003) Gas Transfer Measurements on Young Cocoa Trees in Field and Modeling of Photosynthetic Activity. Proceedings of 14th International Cocoa Research Conference, Accra, 13-18 October 2003, 195-203.

[36] Baligar, V.C., Bunce, J.A., Machado, R.C. and Elson, M.K. (2008) Photosynthetic Photon Flux Density, Carbon Dioxide Concentration and Vapour Pressure Deficit Effects on Photosynthesis in Cacao Seedlings. Photosynthetica, 46, 216-221. https://doi.org/10.1007/s11099-008-0035-7

[37] Yapp, J.H. and Hadley, P. (1994) Inter-Relationships between Canopy Architecture, Light Interception, Vigor and Yield in Cocoa: Implications for Improving Production Efficiency. In: Proceedings of International Cocoa Conference: Challenges in the $90 \mathrm{~s}$, Malaysian Cocoa Board, Kuala Lumpar, 332-350.

[38] Daymond, A.J., Hadley, P., Machado, R.C.R. and Ng, E. (2002) Canopy Characteristics of Contrasting Clones of Cacao (Theobroma cacao L). Experimental Agriculture, 38, 359-367. https://doi.org/10.1017/S0014479702003083

[39] Motamayor, J.C., Lachenaud, P., da Silva e Mota, J.W., Loor, R., Kuhn, D.N., Brown, J.S. and Schnell, R.J. (2008) Geographic and Genetic Population Differentiation of the Amazonian Chocolate Tree (Theobroma cacao L.). PLoS ONE, 3, e3311. https://doi.org/10.1371/journal.pone.0003311

[40] Baligar, V.C., Bunce, J.A., Bailey, B.A., Machado, R.C. and Pomella, W.V. (2005) Carbon Dioxide and Photosynthetic Photon Flux Density Effects on Growth and Mineral Uptake of Cacao. Journal of Food, Agriculture and Environment, 3, 142-147.

[41] Branco, M.C.S., Almeida, A.-A.F., Dalmolin, A.C., Ahnert, D. and Baligar, V.C. (2017) Influence of Low Light Intensity and Soil Flooding on Cacao Physiology. Scientia Horticulturae, 217, 243-257. https://doi.org/10.1016/j.scienta.2017.01.038 
[42] Araújo, R.P., Almeida, A.-A.F., Barroso, J.P., Oliveira, R.A., Gomes, F.P., Ahnert, D. and Baligar, V.C. (2017) Molecular and Morphophysiological Responses Cocoa Leaves with Different Concentrations of Anthocyanin to Variations in Light Levels. Scientia Horticulturae, 224, 188-197. https://doi.org/10.1016/j.scienta.2017.06.008

[43] Baligar, V.C., Elson, M.K., Almeida, A.A.F., de Araujo, Q.R., Ahnert, D. and He, Z. (2021) The Impact of Carbon Dioxide Concentrations and Low to Adequate Photosynthetic Photon Flux Density on Growth, Physiology and Nutrient Use Efficiency of Juvenile Cacao Genotypes. Agronomy, 11, 397. https://doi.org/10.3390/agronomy11020397

[44] Baligar, V.C., Fageria, N.K. and He, Z.L. (2001) Nutrient Use Efficiency in Plants. Communications in Soil Science and Plant Analysis, 32, 921-950. https://doi.org/10.1081/CSS-100104098

[45] Baligar, V.C., Fageria, N.K., Paiva, A.Q., Silveira, A., Pomella, A.W.V. and Machado, R.C.R. (2006) Light Intensity Effects on Growth and Micronutrient Uptake by Tropical Legume Cover Crops. Journal of Plant Nutrition, 29, 1959-1974. https://doi.org/10.1080/01904160600927633

[46] Baligar, V.C., Fageria, N.K., Paiva, A., Silveira, A., Souza Jr., J.O., Lucena, E., Faria, J.C., Cabral, R., Pomella, A.W. and Jorda Jr., J. (2008) Light Intensity Effects on Growth and Nutrient Use Efficiency of Tropical Legume Cover Crops. In: Jose, S. and Gordon, A., Eds., Toward Agroforestry Design: An Ecological Approach, Springer, Dordrecht, 67-79. https://doi.org/10.1007/978-1-4020-6572-9_5

[47] Baligar, V.C., Elson, M.K., He, Z.L., Li, Y.C., Paiva, A.Q., Ahnert, D., Almeida, A.-A.F. and Fageria, N.K. (2017) Ambient and Elevated Carbon Dioxide on Growth, Physiological and Nutrient Uptake Parameters of Perennial Leguminous Cover Crops at Low Light Intensities. International Journal of Plant \& Soil Science, 15, 1-16. https://doi.org/10.9734/IJPSS/2017/32790

[48] Van Vuuren, D.P., Edmonds, J., Kainuma, M., Riahi, K., Thomson, A., Hibbard, K., Hurtt, G.C., Kram, T., Krey, V., Lamarque, J.-F., Masui, T., Meinshausen, M., Nakicenovic, N., Smith, S.T. and Rose, S.K. (2011) The Representative Concentration Pathways: An Overview. Climate Change, 109, Article No. 5. https://doi.org/10.1007/s10584-011-0148-Z

[49] IPCC (2014) Climate Change 2014. Synthesis Report. In: Core Writing Team, Pachauri, R.K. and Meyer, L.A. Eds., Contribution of Working Groups I, II and III th the Fifth Assessment Report of the Intergovernmental Panel on Climate Change, IPCC, Geneva, 151 p.

[50] Van de Geijin, S.C. and Dijkstra, P. (1995) Physiological Effects of Changes in Atmospheric Carbon Dioxide Concentrations and Temperature on Growth and Water Relations of Crop Plants. In: Haverkort, A.J. and Mackerron, D.K.L., Eds., Potato Ecology and Modelling of Crops under Conditions of Limiting Growth, Kluwer Academic Publishers, Dordrecht, 89-99. https://doi.org/10.1007/978-94-011-0051-9_6

[51] Hogan, K.P., Smith, A.P. and Ziska, L.H. (1991) Potential Effects of Elevated $\mathrm{CO}_{2}$ and Changes in Temperature on Tropical Plants. Plant, Cell \& Environment, 14, 763-778. https://doi.org/10.1111/j.1365-3040.1991.tb01441.x

[52] Amthor, J.S. (1995) Terrestrial Higher-Plant Response to Increasing Atmospheric $\left[\mathrm{CO}_{2}\right]$ in Relation to the Global Carbon Cycle. Global Change Biology, 1, 243-274. https://doi.org/10.1111/j.1365-2486.1995.tb00025.x

[53] Long, S.P., Ainsworth, E.A., Rogers, A. and Ort, D.R. (2004) Rising Atmospheric Carbon Dioxide: Plants FACE the Future. Annual Review of Plant Biology, 55, 591-628. https://doi.org/10.1146/annurev.arplant.55.031903.141610 
[54] Galyuon, I.K.A., McDavid, C.R., Lopez, F.B. and Spence, J.A. (1996) The Effect of Irradiance Level on Cocoa (Theobroma cacao L.): II. Gas Exchange and Chlorophyll Fluorescence. Tropical Agriculture (Trinidad), 73, 29-33.

[55] Pound, F.J. (1945) A Note on the Cocoa Population of South America. In: Report and Proceedings of the 1945 Cocoa Conference, the Colonial Office, His Majesty's Stationary Office, London, 131-133.

[56] Lanaud, C., Motamayor, J.C. and Risterucci, A.M. (2001) Implications of New Insight into the Genetic Structure of Theobroma cacao L. for Breeding Strategies. In: Proceedings of the International Workshop on New Technologies for Cocoa Breeding, Ingenic Press, London, 93-111.

https://www.incocoa.org/data/ingenic_workshop_3_proceedings_2000.pdf

[57] Turnbull, C.J. and Hadley, P. (2011) International Cocoa Germplasm Database (ICGD). [Online Database]. NYSE Liffe/CRA Ltd./University of Reading, UK. http://www.icgd.reading.ac.uk

[58] Ahnert, D. and Eskes, A.B. (2018) Developments in Cacao Breeding Programmes in Africa and the Americas. In: Umaharan, P., Ed., Achieving Sustainable Cultivation of Cocoa, Burleigh Dodds Science Publishing, Cambridge, UK, 1-40. https://doi.org/10.19103/AS.2017.0021.06

[59] Jackson, E., Farrington, D.S. and Henderson, K. (1986) The Analysis of Agricultural Materials: A Manual of the Analytical Methods Used by the Agricultural Development and Advisory Service. In: Reference Book, No. 427, 3rd Edition, HMSO, London, 248.

[60] USEPA (2001) Method 200.7, Trace Elements in Water, Solids, and Biosolids by Inductively Coupled Plasma-Atomic Emission Spectrometry. USEPA, Office of Science and Technology, Washington DC.

[61] Bremner, J.M. (1996) Nitrogen Total. In: Sparks, D.L., Ed., Methods of Soil Analysis, Part 3: Chemical Methods, SSSA, Madison, 1085-1122.

https://doi.org/10.2136/sssabookser5.3.c37

[62] Miyaji, K.-I., Da Silva, W.S. and Alvim, P.T. (1997) Productivity of Leaves of a Tropical Tree, Theobroma cacao, Grown under Shading, in Relation to Leaf Age and Light Conditions within the Canopy. New Phytologist, 137, 463-472. https://doi.org/10.1046/j.1469-8137.1997.00841.x

[63] Wullschleger, S.D., Gunderson, C.A., Hanson, P.J., Wilson, K.B. and Norby, R.J. (2002) Sensitivity of Stomatal and Canopy Conductance to Elevated $\mathrm{CO}_{2}$ Concentration-Interacting Variables and Perspectives of Scale. New Phytologist, 153, 485-496. https://doi.org/10.1046/j.0028-646X.2001.00333.x

[64] Lahive, F., Hadley, P. and Daymond, A.J. (2018) The Impact of Elevated $\mathrm{CO}_{2}$ and Water Deficit Stress on Growth and Photosynthesis of Juvenile Cacao (Theobroma cacao L.). Photosynthetica, 56, 911-920. https://doi.org/10.1007/s11099-017-0743-y

[65] Hollinger, D.Y. (1987) Gas Exchange and Dry Matter Allocation Responses to Elevation of Atmospheric $\mathrm{CO}_{2}$ Concentration in Seedlings of Three Tree Species. Tree Physiology, 3, 193-202. https://doi.org/10.1093/treephys/3.3.193

[66] Ziska, L.H., Hogan, K.P., Smith, A.P. and Drake, B.G. (1991) Growth and Photosynthetic Response of Nine Tropical Species with Long-Term Exposure to Elevated Carbon Dioxide. Oecologia, 86, 383-389. https://doi.org/10.1007/BF00317605

[67] Bunce, J.A. (1997) Variation in Growth Stimulation by Elevated Carbon Dioxide in Seedlings of Some $\mathrm{C}_{3}$ Crop and Weed Species. Global Change Biology, 3, 61-66. https://doi.org/10.1046/j.1365-2486.1997.00051.x

[68] Poorter, H. (1993) Interspecific Variation in the Growth Response of Plants to an 
Elevated Ambient $\mathrm{CO}_{2}$ Concentration. Vegetatio, 104, 77-97. https://doi.org/10.1007/BF00048146

[69] Bunce, J.A. (2001) Are Annual Plants Adapted to the Current Atmospheric Concentration of Carbon Dioxide? International Journal of Plant Sciences, 162, 1261-1266. https://doi.org/10.1086/323475

[70] Snoeck, J. (1984) Cacao. In: Martin-Prevel, P., Gagnard, J., Gautier, P., Jones Jr., J.B. and Holmes, M.R.J., Eds., Plant Analysis as a Guide to the Nutrient Requirements of Temperate and Tropical Crops, Lavoisier, New York, 432-439.

[71] Cabala-Rosand, P., Santana, M.B.M. and De Santana, C.J.L. (1989) Cacao. In: Plucknett, D.L. and Sprague, H.B., Eds., Detecting Mineral Nutrient Deficiencies in Tropical and Temperate Crops, Westview Press, Boulder, 409-425. https://doi.org/10.1201/9780429035258-38

[72] Bhargava, B.S. and Raghupathi, H. (1993) Analysis of Plant Materials for Macro and Micronutrients. In: Tandon, H.L.S., Ed., Methods of Analysis of Soils, Plants, Waters and Fertilizers, FDCO, New Delhi, 49-82.

[73] Gerloff, G.C. and Gabelman, W.H. (1983) Genetic Basis of Inorganic Plant Nutrition. In: Lauchli, A. and Bielski, R.L., Eds., Inorganic Plant Nutrition, Springer-Verlog, New York, 5453-5480.

[74] Vose, P.B. (1984) Effects of Genetic Factors on Nutritional Requirement of Plants. In: Vose, P.B. and Blixt, S.G., Eds., Crop Breeding. A Contemporary Basis, Pergamon Press, Oxford, UK, 67-114. https://doi.org/10.1016/B978-0-08-025505-7.50007-5

[75] Baligar, V.C., Elson, M.K., He, Z.L., Li, Y.C., Paiva, A.Q., Ahnert, D. and Almeida, A.-A.F. (2018) Growth, Physiological and Nutrient Uptake Traits of Crotalaria Cover Crops Influenced by Levels of Carbon Dioxide under Low Light Intensities. International Journal of Plant \& Soil Science, 23, 1-14. https://doi.org/10.9734/IJPSS/2018/41846 